\title{
Central bankers as supervisors: Do crises matter?
}

\author{
Donato Masciandaro ${ }^{\mathrm{a}}$, Davide Romelli ${ }^{\mathrm{b}, *}$ \\ a Bocconi University, Milan, Italy and SUERF - The European Money and Finance Forum, Italy \\ b Trinity College Dublin, Ireland
}

\section{A R T I C L E I N F O}

\section{JEL classification:}

E58

E63

G18

Keywords:

Financial supervision

Central banking

Central bank independence

Political economy

Banking supervision

\begin{abstract}
A B S T R A C T
Following the 2007-09 Global Financial Crisis many countries have changed their financial supervisory architecture by increasing the involvement of central banks in supervision. This has led many scholars to argue that financial crises are an important driver in explaining the evolution of the role of central banks as supervisors. We formally test this hypothesis employing a new database that captures the full set of supervisory reforms implemented during the period 1996-2013 in a large sample of countries. Our findings support the view that systemic banking crises are important drivers of reforms in supervisory structure. However, we also highlight an equally important peer effect, namely a tendency of countries to reform their financial supervisory architecture when others do so as well. We construct several measures of spatial spillover effects and show that they can explain institutional similarities among countries and impact the probability of reforming the role of the central bank in financial sector supervision.
\end{abstract}

\section{Introduction}

What explains the reforms in the architecture of financial sector supervision? Throughout the 1990s and early 2000s, the creation of financial sector supervisors independent from the central bank has been generally associated with the reputational failures of many central banks during banking crises (Masciandaro, 2006; Masciandaro and Quintyn, 2009). Yet, following the 2007-09 Global Financial Crisis, many countries have actually increased the involvement of central banks in financial sector supervision, suggesting a sort of "great reversal" towards prudential supervision in the hands of central banks (Dalla Pellegrina et al., 2013). A classical example of this reversal is the evolution of the supervisory architecture in the United Kingdom between 1997 and 2013. In 1997 , when the UK parliament voted to give its central bank operational independence with a clear objective of price stability, the responsibility for banking supervision was transferred from the Bank of England to the Financial Services Authority. However, the supervisory failure of this authority during the recent crisis led to its dismissal in 2013, with the supervisory powers being assigned to the newly established Prudential Regulation Authority, as a part of the Bank of England.

This trend towards increasing the involvement of central banks in financial sector supervision is common to a broader set of countries. Fig. 1 shows the degree of involvement of central banks in financial sector supervision in 1996 as compared to 2013 in a large set of countries. Using a new dataset constructed in this paper, we observe a clear tendency towards assigning central banks with the supervision of the entire financial sector, as darker shades of color depict an increasing number of financial sectors that fall under the responsibility of the central bank.

Yet, economic theory does not provide a clear answer as to whether assigning supervisory roles to central banks or other independent institutions is socially optimal. Masciandaro and Quintyn (2015) highlight two conflicting views regarding the merger of monetary and supervisory functions inside the central bank. An integration view underscores the informational advantages and

\footnotetext{
* Corresponding author.

E-mail address: romellid@tcd.ie (D. Romelli).
} 

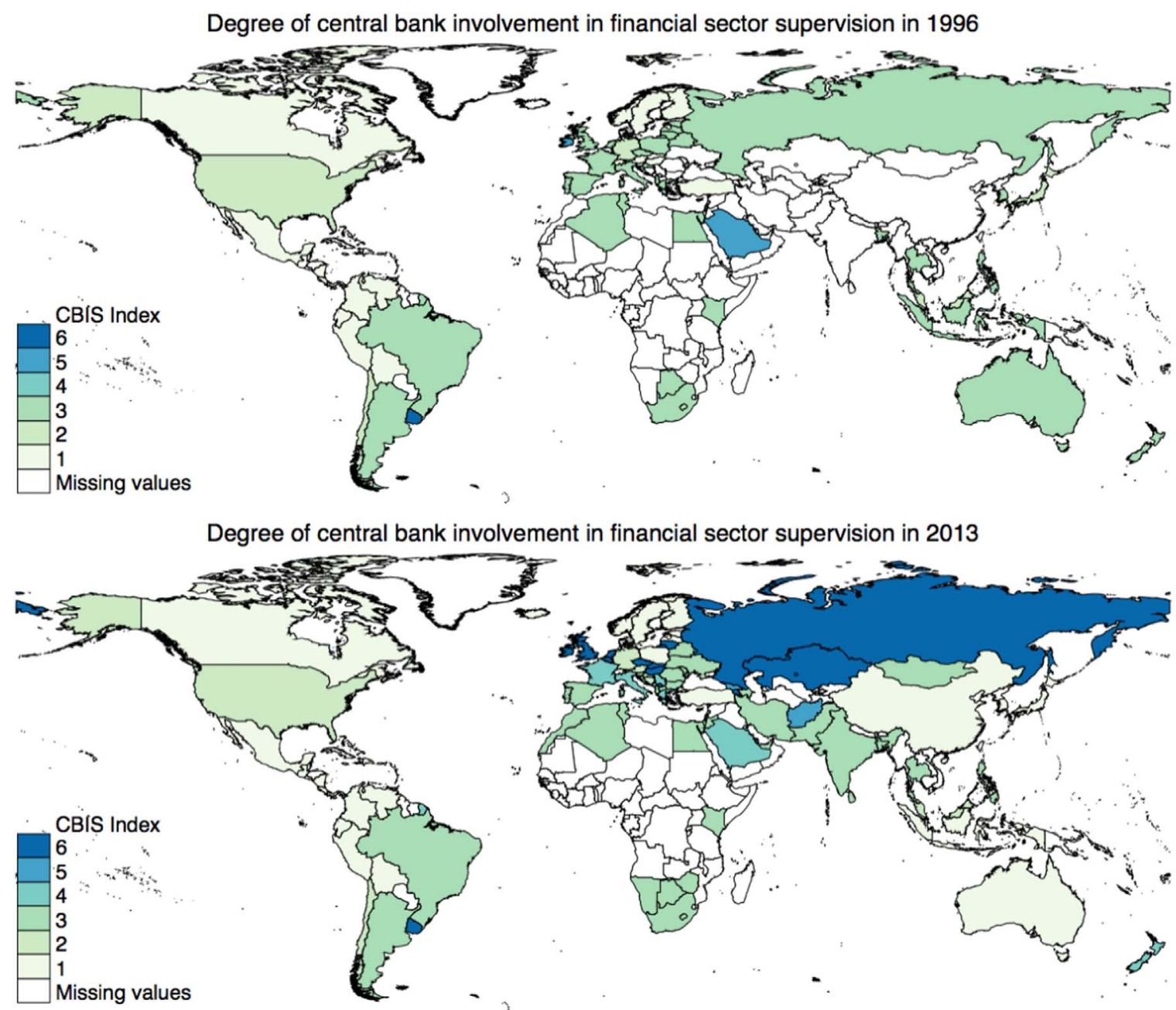

Fig. 1. Evolution of the degree of involvement of central banks in financial sector supervision (1996-2013), Notes: Figure compares the degree of involvement of central banks in financial sector supervision in 1996 as compared to 2013, using the index of central bank involvement in supervision (CBIS) constructed in this paper. Darker colours correspond to an increasing number of sectors that fall under the supervisory responsibilities of the central bank. (For interpretation of the references to color in this figure legend, the reader is referred to the web version of this article.)

economies of scale derived from bringing all functions under the authority of the central bank (Peek et al., 1999; Bernanke, 2007). Alternatively, a separation argument highlights the higher risk of policy failure, as financial stability concerns might impede the implementation of optimal monetary policies (Goodhart and Schoenmaker, 1995; Ioannidou, 2005; Berger and Kißmer, 2013). The empirical literature that has investigated the relative merits of assigning banking sector supervision in the hands of central banks also produces mixed results. ${ }^{1}$

In this paper, we propose a novel approach to understanding the cross-country evolution in the institutional design of financial sector supervisors. Our goal is to understand the determinants of reforms that increase the involvement of central banks in the supervision of the entire financial sector. To that end, we first create a new dataset containing information on the authorities responsible for the oversight of the financial sector (banking, insurance and financial markets) in a large sample of 105 countries, over the period 1996-2013. Using this data, we develop a new index of Central Bank Involvement in Supervision (CBIS Index, hereafter) that captures the roles of the central bank in supervising all, some or none of the different financial sector actors. This new index updates and extends previous attempts to measure financial sector supervision in several ways. First, previous indexes have

\footnotetext{
${ }^{1}$ For example, Arnone and Gambini (2007) find evidence in support of the integration view by highlighting the positive link between compliance with the Basel principles of supervision and the integration of supervisory powers inside the central bank. Peek et al. (1999) show that having supervisory information available improves the efficiency of the monetary policy function. On the other hand, Di Noia and Di Giorgio (1999) support the separation view by showing that inflation rates are higher and more volatile in countries where only the central bank is in charge of banking supervision. Chortareas et al. (2016) document that central banks serving both monetary policy and banking supervision functions are less inflation conservative. Similarly, Ioannidou (2005) finds that the FED's monetary policies do alter its banking supervisory activity, while Dincer and Eichengreen (2012) find evidence that nonperforming loans are lower if banking supervision is assigned to an independent authority different from the central bank.
} 
only focused on the role of central banks in banking sector supervision (Masciandaro, 2006, 2007). However, limiting the concept of supervision solely to the banking sector overlooks the interplay between banks, insurance companies and financial markets, as well as the supervisory challenges posed by international financial conglomerates (De Grauwe, 2008). Second, when the entire financial sector is considered, as in Melecky and Podpiera (2013), the focus has been on whether the supervision is unified or under the control of separate institutions. At difference, in this paper, we are concerned with the increasing role of the central bank in supervision. Hence, our index assesses whether countries adopt a unified financial sector supervision inside the central bank. Finally, our larger panel of countries and time span, allows us to construct the full set of reforms in the institutional design of financial sector supervision.

Our main contribution rests in understanding what drives countries to modify their supervisory architecture over time. To our knowledge, this is the first study to investigate the triggers of reforms in the institutional design of financial sector supervision. In line with popular belief, we find that past episodes of systemic banking crises significantly increase the probability that a country reforms its supervisory structure. This result is specific to financial sector turmoil and not other types of crises, such as currency crises or economic recessions. Moreover, we find that crises are followed by reforms that generally increase the involvement of central banks in financial sector supervision, but not by those that decrease it.

Given this result, a natural question arises: in the absence of random shocks to the financial sector or an optimal institutional setting, what shapes the supervisory architecture of a country? We document an important "peer" effect among countries that explains the evolution of financial sector supervision. In particular, we find that countries are more likely to change their supervisory architecture when the share of countries undertaking reforms around the world or in the same continent is higher. We also employ recent spatial econometric techniques to construct groups of peer countries based on geographical distance and trade relationships (see also Elhorst et al., 2013). Our findings suggest that countries whose financial architecture is farther from the average of their peer group are more likely to reform. These results complement a recent literature that stresses the importance of an international convergence in institutional design (Abiad and Mody, 2005; Persson and Tabellini, 2009).

We also investigate whether certain country characteristics are associated with the prevalence of a given type of institutional design of financial supervision. This complements the findings in Melecky and Podpiera (2013) who identify a series of determinants of unified financial sector supervision. In this paper, we focus on the determinants of a unified supervision, but in the hands of the central bank. Our results show that the degree of central bank independence is highly relevant in influencing the decision to concentrate financial sector supervision in the hands of monetary policy authorities. Specifically, higher central bank independence is associated with a lower central bank involvement in supervision. Thus, not only does higher independence suggest more decentralised supervision as Melecky and Podpiera (2013) find, but also less involvement of central banks in the oversight of the financial sector. This is in line with the view that granting the unified supervisory power to an already highly independent central bank might increase the risk of bureaucratic misconduct (Masciandaro, 2009).

The sensitivity of our findings is subjected to a variety of robustness tests, including various econometric specifications, alternative measures of peer countries, controlling for the direction of reforms or for alternative definitions for the index of central bank involvement in supervision.

The outline of the paper is as follows. Section 2 discusses the methodology followed in building the index of supervisory unification inside the central bank. In Section 3 we discuss the empirical strategies followed and the data. Section 4 presents the main results, while Section 5 concludes.

\section{Supervision and central banking: metrics and stylised facts}

This section details the new database on financial sector supervisory authorities. We collect information on the institutions responsible for financial supervision in 105 countries from 1996 to $2013 .^{2}$ This data was mainly obtained from websites, as well as charters of central banks and/or national supervisory authorities across the world. ${ }^{3}$ In order to capture the degree of central bank involvement in financial sector supervision, we create a consolidated index of central bank involvement in supervision (CBIS Index). This index takes the maximum (minimum) score in countries where all (no) supervisory responsibilities are assigned to the central bank.

The construction of this index entails the following steps. First, we identify which is the authority in charge of the supervision of the following three sectors: i) banking, ii) insurance, and iii) securities markets. Whenever we find that the central bank is the supervisor of one of these financial institutions, we ask whether this responsibility is shared or not with other authorities. Next, we classify for each country the financial sectors whose supervision is assigned to the central bank. Finally, we transform this qualitative information into quantitative indicators, by assigning a value to the degree of supervisory unification in the hands of the monetary policy authority. The CBIS index distinguishes among the following levels of unification:

(A) A unified supervision of the entire financial sector inside the central bank (6 points).

(B) A unified supervision of the banking and securities markets sectors inside the central bank (5 points).

\footnotetext{
${ }^{2}$ Not all countries have information for the entire period, hence our panel is unbalanced. Appendix Table A1 presents the full set of countries and information on data availability. Furthermore, Appendix Table A2 provides information on the authorities responsible for financial sector supervision as of end-2013 for the set of analysed countries.

${ }^{3}$ To ensure completeness of information, we have cross-checked this information with the 2005-2013 editions of How countries supervise their banks, insurers and securities markets, which provide contact details for key regulatory decision-makers in 189 jurisdictions (Courtis, 2010).
} 
(C) A unified supervision of the banking and insurance sectors inside the central bank (4 points).

(D) Only banking supervision is in the hands of the central bank (3 points).

(E) Banking supervision is shared between the central bank and another authority (2 points).

(F) The central bank is not involved in supervision (1 point).

The different levels of integration assumed by this index are based on previous measures of financial sector supervision proposed in Masciandaro (2006, 2009) and Melecky and Podpiera (2013). We extend these indicators in several ways. First, our main motivation for the hierarchical structure proposed in the CBIS index is driven by the fact that the data collected shows that central banks are either involved in banking supervision and some or none of the other sectors, or have not supervisory responsibilities at all. This puts the banking supervisory function of the central bank at the centre of our index. This differs from the index in Masciandaro $(2006,2009)$ which assigns a maximum of points whenever there is a unique supervisory authority regardless of whether this institution is the central bank. Moreover, the index proposed here brings a higher level of detail as compared to previous ones, by considering all possible levels of integration of financial sector supervision. ${ }^{4}$

Our measure also differs from the index in Melecky and Podpiera (2013), which distinguishes between unified prudential supervision in the hands of an independent authority or of the central bank. Their measure of supervisory unification assigns lower values for a sectorial supervision outside (1 point) or inside ( 2 points) the central bank and reaches the maximum value for unified supervision in the hands of the central bank (4 points). However, previous research shows that countries are more likely to follow a path dependence in assigning financial supervision inside or outside the central bank (Masciandaro, 2006). More specifically, countries characterised by a sectorial supervision outside the central bank are more likely to reform their supervisory architecture towards a unified supervisor outside the central bank. On the other hand, whenever the monetary policy authority is already responsible for banking supervision, the move towards a unified financial sector supervision tends to place full supervisory powers in the hands of the central bank. For this reason, we consider a unified financial sector supervision inside or outside the central bank to be at the extreme opposite points of our index, an element that is not clearly distinguishable in previous categorisation.

Based on our new index of supervisory responsibilities, we find that $75 \%$ of the countries in our sample have reformed their financial supervisory architecture at least once over the period 1996-2013 by establishing a new supervisory authority and/or changing the power of at least one of the already existing supervisors. Moreover, a third of these reforms involved changes in the role of central banks in financial sector supervision. ${ }^{5}$

Fig. 2 shows the magnitude of the changes in supervisory architecture between 1996 and 2013. A trend towards an increasing supervision in the hands of the central bank can be noticed in recent years, given that positive changes in the value of the CBIS Index correspond to an increased concentration of supervisory powers inside the central bank. At the same time, this trend appears even stronger after the 2007-09 Global Financial Crisis. Prior to this, during 1996-2007, most supervisory reforms undertaken reduced the degree of central bank involvement. However, this trend is reverted after the crisis, with most countries moving towards a higher concentration of supervision in the hands of the central bank (as depicted in the upper-right quadrant of Fig. 2). In fact, if we look at the 19 reforms that took place since the beginning of the recent crisis, we find that 15 of them increased the involvement of central banks in financial supervision. This is in line with the belief that financial crises might largely influence the decision to implement reforms in the supervisory architecture. Indeed, the reputational failures of many supervisory institutions have reinforced the idea that banking supervisors need the market expertise and professional economists of central banks and could be more efficient as a built-in function of central banking (Goodhart, 2008).

Fig. 3 corroborates this idea by showing the institutional setting adopted by the countries that reformed their financial sector supervision during 1996-2013. Interestingly, in a third of the reforms implemented prior to 2007, supervisory powers have been removed from the central bank and assigned to an independent unified supervisor. In a few cases, supervisory responsibilities have even been assigned to different sectorial authorities. After 2007, however, only three countries completely removed supervision from their monetary policy institution, with the aim of creating a unified supervisory authority outside the central bank. On the other hand, out of the 19 reforms implemented since 2007, in 9 cases the central bank has become the unique supervisor of the financial sector.

These descriptive statistics motivate our empirical investigation, by placing episodes of financial distress at the centre of the reform process. However, the historical evolution of supervisory architectures also suggests some cyclical patterns (see Ugolini, 2011). In the decades prior to 1996, several central banks were strongly involved in supervisory activities, which were considered thoroughly integrated with the overall responsibility of central banks to manage liquidity (see also Toniolo, 2011). However, as our data suggests, a reversal occurred afterwards, associated with a decrease in the involvement of central banks in supervision. This reversal could have started with the 1997 Asian financial crisis. For example, prior to this crisis, banking sector supervision in Japan and South Korea was conducted by the central bank. However, in the aftermath of the crisis, South Korea reformed its financial supervisory architecture by creating a single supervisory authority independent from the central bank. In the same year, 1998, Japan created the independent Financial Supervisory Agency that became responsible for the supervision of the Japanese financial sector. The trend that followed the 2007 financial crisis suggests a shift in the opposite direction, towards more involvement. This evolution, suggests that, while crises might spark the reform process, some international convergence towards a similar institutional setting

\footnotetext{
${ }^{4}$ We, nonetheless, consider the robustness of our results when different levels of aggregation are employed.

${ }^{5}$ Appendix Table A3 shows the list of countries that modified their supervisory architecture by re-shaping the central bank involvement in financial sector supervision.
} 


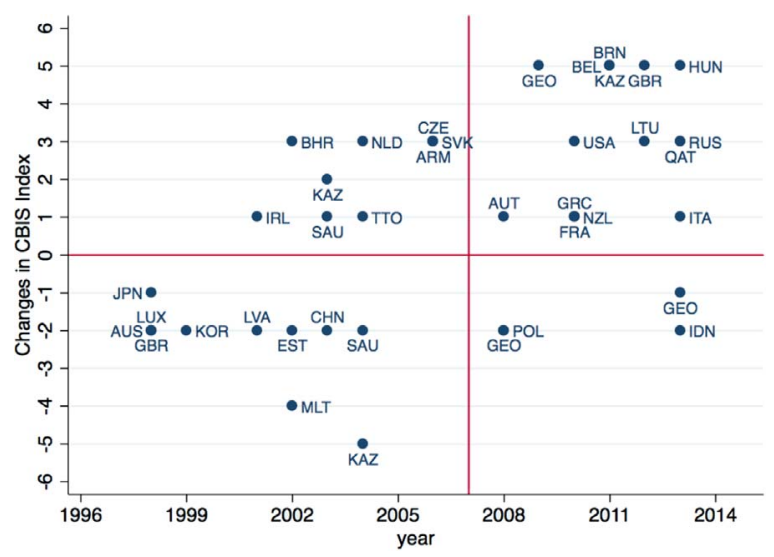

Fig. 2. Magnitude of reforms in CBIS (1996-2013), Notes: Figure summarizes the magnitude of reforms that modified the degree of central bank involvement in financial sector supervision between 1996 and 2013. Positive/Negative changes in the CBIS index indicate an higher/lower involvement of the central bank in supervision.

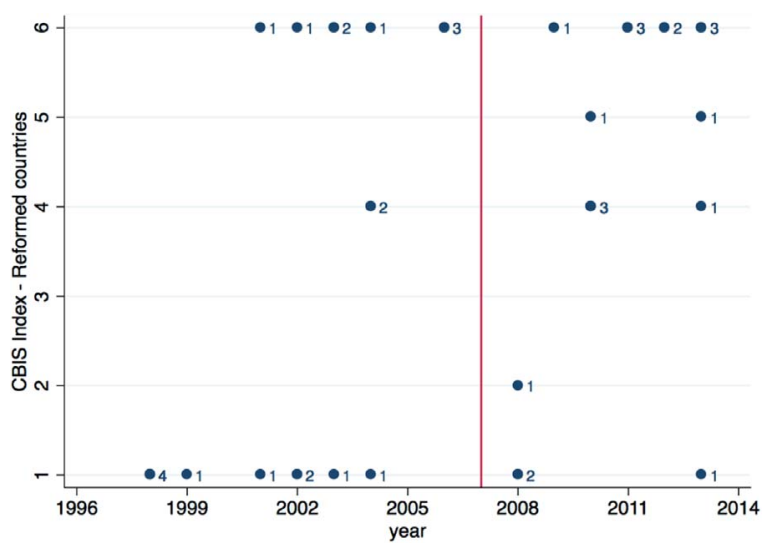

Fig. 3. Direction of reforms in CBIS (1996-2013), Notes: This figure indicates the institutional setting adopted by the countries that reformed their financial sector supervision between 1996 and 2013. Values reported next to each point indicate the number of countries that reformed their supervisory architecture in the year and adopted the specific level of central bank involvement in financial sector supervision.

might also exist. As a result, our second empirical interest rests in uncovering whether countries "learn" or imitate their peers when reforming their financial supervisory architecture.

\section{Supervision and central banking: main drivers of reforms}

Our main empirical investigation aims at identifying the drivers of reforms in supervisory architecture. Based on the patterns of reforms suggested by the descriptive statistics in the previous section and a large literature on the political economy of reforms, we consider three sets of factors that could potentially impact the probability of reforming: (i) episodes of financial crises, (ii) bandwagon or peer effects and (iii) domestic factors. We estimate the role of these factors on the conditional probability of having a reform in the architecture of supervisory authorities using the following specification:

$$
\operatorname{Prob}\left(e_{i t}=1\right)=F\left(\phi_{t}^{\text {Crises }} \beta_{C}+\phi_{t}^{\text {Bandwagon }} \beta_{B}+\phi_{t}^{\text {Domestic }} \beta_{D}\right) \text {, }
$$

where $e_{i t}$ is a dummy variable that takes the value 1 if country $i$ has implemented a supervisory reform that modifies the CBIS index in year $t ; \phi_{t}^{\text {Crises }}$ is a dummy for crises episodes; $\phi_{t}^{\text {Bandwagon }}$ captures different proxies for bandwagon effects; and $\phi_{t}{ }^{\text {Domestic }}$ is a vector of country-specific characteristics. The appropriate methodology to estimate Eq. (1) is determined by the distribution of the cumulative distribution function, $F(\cdot)$. Because reforms occur irregularly ( $97.5 \%$ of the sample is zeros), $F(\cdot)$ is asymmetric. Therefore, we estimate Eq. (1) using the complementary logarithmic (or cloglog) framework, which assumes that $F(\cdot)$ is the cumulative distribution function (cdf) of the extreme value distribution. In other words, this estimation strategy assumes that: ${ }^{6}$

$$
F(z)=1-\exp [-\exp (z)] .
$$

\footnotetext{
${ }^{6}$ This methodology represents an alternative to logit and probit models and is typically used when the positive (or negative) outcome is rare (i.e. the number of zeros is large). This is also the case here, since reforms do not happen that often in our sample of 1800 country-year observations.
} 
The impact of financial crises on the probability of reforms is captured by a crisis dummy that signals the presence of a systemic banking crisis in the previous two years. The date of the crisis comes from Laeven and Valencia (2013) who identity the beginning and end date of systemic banking crises in a large set of countries. To construct our dummy, we ask whether any of the two years prior to a reform coincides with a year that Laeven and Valencia (2013) classify as crisis year. If so, the Financial Crisis variable takes the value one. Note that we do not include the year of the reform in this definition to avoid any endogeneity concerns, such as the crisis being caused by the reform itself. ${ }^{7}$ Our hypothesis is that policy makers consider financial crises as signals of supervisory failure of a certain architecture. We thus expect such crises to have a positive impact on the probability of reforming. However, whether the reform will result in a consolidation of supervision inside the central bank is not, a priori, clear.

Second, we argue that the probability of reforming financial supervision architecture is connected to an international convergence among peer countries. Masciandaro et al. (2008) call this a bandwagon effect and argue that the high level of cooperation between central banks might stimulate a process through which these institutions learn from and follow the policy changes implemented by their peers (see also Borio et al., 2011). This is also suggested by a related literature that highlights the importance of peers at the firm level (Leavy and Robert, 2014) or at the country level (Abiad and Mody, 2005).

We use several indicators to proxy the role played by peer pressure in the diffusion of reforms in financial supervision. The first measure, called "Reforms in CBIS (World)", computes the share of countries around the world that are undertaking a supervisory reform (that modifies CBIS) in year $t$. This variable provides an indicator of the "popularity" of undertaking reforms, i.e., if financial supervisory reforms are fashionable in a certain year, the probability that country $i$ undertakes a reform in year $t$ is positively related with the share of countries that are currently undertaking reforms. Similarly, we define a variable "Reforms in CBIS (Continent)", as the share of countries that are undertaking a supervisory reform in year $t$ and are located in the same continent as country $i$.

The second set of measures of bandwagon effects are based on spatial spillover effects among countries. Similar techniques are employed in recent literature to explain the existence of peer effects among countries. For example, Abiad and Mody (2005) build a measure of regional diffusion that focuses on the distance of individual countries from their regional leaders to explain the diffusion of financial liberalisation. Similarly, Persson and Tabellini (2009) use the weighted average of democracy among neighbours to estimate the impact of a country's "democratic capital" on growth. We propose a similar measure of closeness of country $i$ 's supervisory architecture with respect to its neighbouring countries. Specifically, this measure, denoted by Peers $s_{i, t}$, is the absolute value of the difference between a country's CBIS index and its peers, as follows:

$$
\operatorname{Peers}(\rho)_{i, t}=\left|\sum_{i \neq j}\left(C B I S_{i}-C B I S_{j}\right) \bar{\omega}(\rho)_{t}^{j, i}\right|,
$$

where $C B I S_{i}$ is a measure of the level of CBIS in the base country $i$ in year $t$ and $C B I S_{j}$ is a measure of the level of CBIS in peer country $j$ in year $t$. The weights $\bar{\omega}(\rho)_{t}^{j, i}$ are obtained from the inverse distance matrix between pair countries, and drops to zero for countries outside the radius $\rho .^{8}$ We consider two alternative specifications for the matrix $\bar{\omega}(\rho)_{t}^{j, i}$. In the first, the distance between countries is based on the geographical location. This measure, denoted by Peers - Geographical, assigns a weight to each peer country based on the physical distance from the reference country. Closer countries are assigned a higher weight based on the inverse distance matrix. We follow Elhorst et al. (2013) and assume a $3000 \mathrm{~km}$ radius for the distance. ${ }^{9}$ Data on geographical distance is obtained from the distance database of the CEPII (Mayer and Zignago, 2011).

The second measure, denoted Peers - Trade, is based on the bilateral trade among countries. The assumption is that countries with close trading relationships should also exhibit stronger spillover effects. We thus employ bilateral trade data from the CEPII and order it by the size of trade between countries. For each country, we then retain the $25 \%$ largest trading partners as the size of $\rho$ and use these trading values to create the inverse distance matrix.

The last set of determinants of reforms in CBIS follows a large political economy literature and includes several country characteristics. First, we hypothesize that reforms in central bank institutional design might also influence the degree of central banks' involvement in supervision. This is in line with the idea that reform processes are likely to be enacted at the same time. Given our panel dataset of reforms in CBIS, we obtain the full set of reforms in central bank independence as a mainstream measure of central bank institutional design from Arnone and Romelli (2013) and Romelli (2016). These reforms are based on changes of the Grilli et al. (1991) index over time. This index, however, also provides information on the involvement of central banks in banking supervision. As a result, the dummy variable for legislative reforms in CBI takes the value one only in years in which changes in the other characteristics of central bank institutional design took place. ${ }^{10}$

Furthermore, Masciandaro (2009) builds a political economy model to study the determinants of supervisory architectures and shows that the quality of public sector governance plays an important role. Based on these arguments one can expect that changes in the political orientation of the government might stimulate the implementation of reforms. We capture this effect through a dummy variable that indicates changes in the political orientation of the government that took place up to two years prior to a reform in

\footnotetext{
${ }^{7}$ As robustness checks, we show nonetheless that our results hold when the crisis and reform year coincide and we include this year in our definition of the financial crisis dummy.

${ }^{8}$ At difference with previous studies, we look at the absolute value of this measure, since higher (or lower) values of our index cannot be interpreted as better (or worse) outcomes. This is clearly not the case in the literature on democracy or financial liberalisations, where the leading countries are generally considered the ones characterised by higher value of the respective index.

${ }^{9}$ In unreported results, robustness checks are performed using the 2000,4000 and $5000 \mathrm{~km}$ radius.

${ }^{10}$ Details on the construction of this index are provided in Appendix Table A4 (see also Cukierman, 2008).
} 
Table 1

Determinants of reforms in financial sector supervision: baseline results.

\begin{tabular}{|c|c|c|c|c|c|c|}
\hline & (1) & (2) & (3) & (4) & $(5)$ & (6) \\
\hline Financial Crisis & $\begin{array}{l}0.662 \\
(0.375)\end{array}$ & $\begin{array}{l}0.874^{*} \\
(0.458)\end{array}$ & $\begin{array}{l}0.833^{* * *} \\
(0.386)\end{array}$ & $\begin{array}{l}0.866^{*} \\
(0.468)\end{array}$ & $\begin{array}{l}0.936^{*} \\
(0.500)\end{array}$ & $\begin{array}{l}1.129^{* * *} \\
(0.518)\end{array}$ \\
\hline Reforms in CBIS (World) & $\begin{array}{l}0.471 \\
(0.092)\end{array}$ & $\begin{array}{l}0.531^{\text {***** }} \\
(0.135)\end{array}$ & & & $\begin{array}{l}0.045 \\
(1.061)\end{array}$ & \\
\hline Reforms in CBIS (Continent) & & & $\begin{array}{l}0.110^{\text {***** }} \\
(0.020)\end{array}$ & $\begin{array}{l}0.086^{* * * * *} \\
(0.015)\end{array}$ & & $\begin{array}{l}0.081^{* * * *} \\
(0.019)\end{array}$ \\
\hline Reforms in CBI & & $\begin{array}{l}0.719 \\
(0.576)\end{array}$ & & $\begin{array}{l}1.288^{* * *} \\
(0.550)\end{array}$ & $\begin{array}{l}1.032^{*} \\
(0.611)\end{array}$ & $\begin{array}{l}1.331^{* * *} \\
(0.611)\end{array}$ \\
\hline Government Change & & $\begin{array}{l}0.555 \\
(0.457)\end{array}$ & & $\begin{array}{l}0.693 \\
(0.478)\end{array}$ & $\begin{array}{l}0.535 \\
(0.460)\end{array}$ & $\begin{array}{l}0.650 \\
(0.482)\end{array}$ \\
\hline Governance & & $\begin{array}{l}0.269 \\
(0.353)\end{array}$ & & $\begin{array}{l}0.125 \\
(0.364)\end{array}$ & $\begin{array}{l}0.285 \\
(0.358)\end{array}$ & $\begin{array}{l}0.175 \\
(0.375)\end{array}$ \\
\hline OECD Dummy & & $\begin{array}{l}1.378^{* * *} \\
(0.654)\end{array}$ & & $\begin{array}{l}1.302^{*} \\
(0.682)\end{array}$ & $\begin{array}{l}1.423^{* * *} \\
(0.668)\end{array}$ & $\begin{array}{l}1.352^{*} \\
(0.692)\end{array}$ \\
\hline Polity & & $\begin{array}{l}-0.126^{\text {***** }} \\
(0.043)\end{array}$ & & $\begin{array}{l}-0.128^{* * * *} \\
(0.044)\end{array}$ & $\begin{array}{l}-0.127^{\text {*****}} \\
(0.043)\end{array}$ & $\begin{array}{l}-0.126 \\
(0.044)\end{array}$ \\
\hline Civil Law Dummy & & $\begin{array}{l}-1.139^{* * * *} \\
(0.431)\end{array}$ & & $\begin{array}{l}-0.837^{*} \\
(0.443)\end{array}$ & $\begin{array}{l}-1.139^{* * * * *} \\
(0.430)\end{array}$ & $\begin{array}{l}-0.913^{\text {*** }} \\
(0.444)\end{array}$ \\
\hline Observations & 1839 & 1303 & 1839 & 1303 & 967 & 967 \\
\hline Number of Countries & 105 & 94 & 105 & 94 & 94 & 94 \\
\hline Year FE & & & & & YES & YES \\
\hline
\end{tabular}

The dependent variable is a reform dummy that takes the value one in the year when the CBIS index changes. Financial Crisis is a dummy variable that takes the value one if any of the two years prior to a reform year are classified as a systemic banking crisis year in Laeven and Valencia (2013). Reforms in CBIS (World/Continent) represent the share of countries that have reformed their financial supervisory structure in the world/continent in the same year. Reforms in CBI is a dummy variable for countries undertaking reforms that modified the degree of independence of their central banks in the same year. Government Change is a dummy variable that indicates whether a change of the executive party took place in the past two years. Governance is the average value of the Worldwide Governance Indicators (WGI) from the World Bank. Polity is a variable capturing the level of democracy of a country. Constant terms are included, but not reported. Clustered standard errors in parentheses.

${ }^{* * * *}$ denotes significance at a $1 \%$ level.

** denotes significance at a $5 \%$ level.

" denotes significance at a $10 \%$ level.

supervision. We further consider a governance and a democracy index as other political economy variables that might influence the likelihood of supervisory reforms. Additional country-specific controls include a dummy variable that indicates membership to the OECD, as a proxy for economic development, and a dummy variable for civil law countries, as a proxy for the legal origin hypothesis (La Porta et al., 1999; Masciandaro et al., 2008).

\section{Empirical results}

\subsection{Reforms in financial supervision}

Tables 1 and 2 present the estimations obtained using the complementary logarithmic framework in Eq. (1) to predict the probability of reforming the supervisory architecture over the period 1996-2013. Table 1 considers the first set of proxies of bandwagon effects captured by the share of countries reforming financial supervisory architecture the same year, while Table 2 looks at the two proxies that measure a country's "closeness" to its geographical and trading peers, respectively.

Columns (1) and (3) in Table 1 present the baseline regressions which include the financial crisis dummy and the share of countries reforming around the world (in column (1)) and in the same continent (in column (3)). The results show a strong correlation between the crisis dummy and the likelihood of reforms in central bank involvement in supervision. The positive sign suggests that countries experiencing a systemic banking crisis in the two previous years are more likely to reform their supervisory architecture. ${ }^{11}$ This result

\footnotetext{
${ }^{11}$ We have also checked the robustness of the estimations in Tables 1 and 2 when looking at the occurrence of financial crises in the last five years. Results are qualitatively unchanged and are available upon request.
} 
Table 2

Determinants of reforms in financial sector supervision: alternative proxies for peer effects.

\begin{tabular}{|c|c|c|c|c|c|c|}
\hline & (1) & (2) & (3) & (4) & (5) & (6) \\
\hline Financial Crisis & $\begin{array}{l}0.652^{*} \\
(0.376)\end{array}$ & $\begin{array}{l}0.740^{*} \\
(0.386)\end{array}$ & $\begin{array}{l}0.818^{* * *} \\
(0.395)\end{array}$ & $\begin{array}{l}0.983^{* * *} \\
(0.418)\end{array}$ & $\begin{array}{l}0.667 \\
(0.428)\end{array}$ & $\begin{array}{l}0.9012^{* *} \\
(0.442)\end{array}$ \\
\hline Peers - Geographical & $\begin{array}{l}1.246^{* * * *} \\
(0.226)\end{array}$ & $\begin{array}{l}1.505^{*} \\
(0.416)\end{array}$ & & & $\begin{array}{l}1.519^{* * * *} \\
(0.421)\end{array}$ & \\
\hline Peers - Trade & & & $\begin{array}{l}1.063^{\text {***** }} \\
(0.177)\end{array}$ & $\begin{array}{l}1.102^{* * *} \\
(0.240)\end{array}$ & & $\begin{array}{l}1.103^{\text {**** }} \\
(0.233)\end{array}$ \\
\hline Reforms in CBI & & $\begin{array}{l}1.001 \\
(0.759)\end{array}$ & & $\begin{array}{l}0.690 \\
(0.883)\end{array}$ & $\begin{array}{l}1.016 \\
(0.755)\end{array}$ & $\begin{array}{l}0.711 \\
(0.879)\end{array}$ \\
\hline Government Change & & $\begin{array}{l}1.091^{*} \\
(0.626)\end{array}$ & & $\begin{array}{l}0.851 \\
(0.575)\end{array}$ & $\begin{array}{l}1.093^{*} \\
(0.619)\end{array}$ & $\begin{array}{l}0.858 \\
(0.567)\end{array}$ \\
\hline Governance & & $\begin{array}{l}-0.686 \\
(0.522)\end{array}$ & & $\begin{array}{l}-0.513 \\
(0.465)\end{array}$ & $\begin{array}{l}-0.715 \\
(0.533)\end{array}$ & $\begin{array}{l}-0.535 \\
(0.469)\end{array}$ \\
\hline OECD Dummy & & $\begin{array}{l}2.008^{* * *} \\
(0.875)\end{array}$ & & $\begin{array}{l}1.858^{* * *} \\
(0.746)\end{array}$ & $\begin{array}{l}2.031^{* * *} \\
(0.879)\end{array}$ & $\begin{array}{l}1.881^{* *} \\
(0.749)\end{array}$ \\
\hline Polity & & $\begin{array}{l}-0.088 \\
(0.060)\end{array}$ & & $\begin{array}{l}-0.054 \\
(0.049)\end{array}$ & $\begin{array}{l}-0.086 \\
(0.060)\end{array}$ & $\begin{array}{l}-0.053 \\
(0.048)\end{array}$ \\
\hline Civil Law Dummy & & $\begin{array}{l}-0.663 \\
(0.518)\end{array}$ & & $\begin{array}{l}-0.942^{* *} \\
(0.464)\end{array}$ & $\begin{array}{l}-0.681 \\
(0.511)\end{array}$ & $\begin{array}{l}-0.962^{\text {*** }} \\
(0.451)\end{array}$ \\
\hline Observations & 1201 & 954 & 1167 & 924 & 954 & 924 \\
\hline Number of Countries & 102 & 92 & 99 & 89 & 92 & 89 \\
\hline Year FE & YES & YES & YES & YES & YES & YES \\
\hline
\end{tabular}

The dependent variable is a reform dummy that takes the value one in years when the CBIS index changes. Financial Crisis is a dummy variable that takes the value one if any of the two years prior to a reform year are classified as a systemic banking crisis year in Laeven and Valencia (2013). In columns (5) and (6), this crisis dummy includes crises occurring in the same year as the reform. Peers - Geographical/Trade represents the absolute distance between a country's level of CBIS and that of its peers, where the average value of CBIS of peer countries is computed based on geographical distance and trading partners, respectively. Reforms in CBI is a dummy variable for countries undertaking reforms that modified the degree of independence of their central banks in the same year. Government Change is a dummy variable that indicates whether a change of the executive party took place in the past two years. Governance is the average value of the Worldwide Governance Indicators (WGI) from the World Bank. Polity is a variable capturing the level of democracy of a country. Constant terms are included, but not reported. Clustered standard errors in parentheses.

**** denotes significance at a $1 \%$ level.

*** denotes significance at a $5 \%$ level.

" denotes significance at a $10 \%$ level.

supports the idea that crises provide a strong impetuous to reform (see also Agnello et al., 2015; Waelti, 2015). It also complements other recent findings, such as Artha and de Haan (2015) who find that systemic banking crises, but also debt crises, significantly increase the likelihood that a central bank governor is dismissed (see also Dreher et al., 2008).

Importantly, our baseline estimations also suggest a strong peer effect among countries. The positive and statistically significant coefficients of Reforms in CBIS (World) and Reforms in CBIS (Continent) imply that countries are more inclined to change their supervisory architecture the higher is the share of countries implementing reforms across the world or in the same continent. This suggests important international spillovers in institutional design.

These results are robust to the inclusion of additional control variables. Among these, we find no evidence that government changes or good governance play an important role in explaining supervisory reforms. However, legislative changes that modify the degree of central bank independence do exert some effect on the likelihood of reforming financial supervision as well. More advanced economies (OECD countries) also appear more likely to change their supervisor, while civil law countries present a lower probability of reforming the involvement of their central bank in financial supervision. Finally, columns (5) and (6) in Table 1 control for time fixed effects that account for any shocks that affect all countries in a given year.

Table 2 repeats the same econometric exercise by including the second set of bandwagon variables, namely the peer pressure coming from regional and trading partners. Columns (1)-(2) consider the distance between a country's supervisory architecture and that of its geographical neighbours, while columns (3)-(4) consider the distance between a country and its closest trading partners. The results are highly robust under these alternative peer effects measures and suggest that countries face an international pressure to reform. The higher the distance between a country's institutional setting and that of its trading or geographical peers, the more likely the reform process. Similar to Table 1, Columns (2) and (4) consider a larger set of country-specific characteristics. In columns (5)-(6) we include an alternative definition for the crisis dummy. In our baseline results, this variable took the value 1 if a banking 
Table 3

Determinants of positive/negative changes in CBIS.

\begin{tabular}{|c|c|c|c|c|c|c|c|c|}
\hline & \multicolumn{4}{|c|}{ Reforms that increase CBIS } & \multicolumn{4}{|c|}{ Reforms that decrease CBIS } \\
\hline & (1) & (2) & (3) & (4) & (5) & (6) & (7) & (8) \\
\hline Financial Crisis & $\begin{array}{l}1.029^{* * *} \\
(0.404)\end{array}$ & $\begin{array}{l}0.735 \\
(0.575)\end{array}$ & $\begin{array}{l}1.231^{* * * * *} \\
(0.456)\end{array}$ & $\begin{array}{l}1.073^{*} \\
(0.609)\end{array}$ & $\begin{array}{l}-0.195 \\
(0.793)\end{array}$ & $\begin{array}{l}0.534 \\
(0.788)\end{array}$ & $\begin{array}{l}0.099 \\
(0.822)\end{array}$ & $\begin{array}{l}0.428 \\
(0.850)\end{array}$ \\
\hline Increases in CBIS (World) & $\begin{array}{l}0.762 \\
(0.133)\end{array}$ & $\begin{array}{l}0.839^{* \ldots * *} \\
(0.208)\end{array}$ & & & & & & \\
\hline Increases in CBIS (Continent) & & & $\begin{array}{l}0.111^{* * *} \\
(0.045)\end{array}$ & $\begin{array}{l}0.093 \\
(0.036)\end{array}$ & & & & \\
\hline Reversals in CBIS (World) & & & & & $\begin{array}{l}0.620 \\
(0.090)\end{array}$ & $\begin{array}{l}0.602 \\
(0.115)\end{array}$ & & \\
\hline Reversals in CBIS (Continent) & & & & & & & $\begin{array}{l}0.153^{*} \\
(0.088)\end{array}$ & $\begin{array}{l}0.116 \\
(0.753)\end{array}$ \\
\hline Reforms in CBI & & $\begin{array}{l}0.400 \\
(1.089)\end{array}$ & & $\begin{array}{l}0.398 \\
(1.082)\end{array}$ & & $\begin{array}{l}1.207 \\
(1.040)\end{array}$ & & $\begin{array}{l}2.184 \\
(1.720)\end{array}$ \\
\hline Government Change & & $\begin{array}{l}0.536 \\
(0.711)\end{array}$ & & $\begin{array}{l}0.718 \\
(0.666)\end{array}$ & & $\begin{array}{l}0.545 \\
(0.786)\end{array}$ & & $\begin{array}{l}0.764 \\
(5.895)\end{array}$ \\
\hline Governance & & $\begin{array}{l}0.538 \\
(0.421)\end{array}$ & & $\begin{array}{l}0.423 \\
(0.401)\end{array}$ & & $\begin{array}{l}-0.315 \\
(0.464)\end{array}$ & & $\begin{array}{l}-0.470 \\
(0.509)\end{array}$ \\
\hline OECD Dummy & & $\begin{array}{l}0.837 \\
(0.715)\end{array}$ & & $\begin{array}{l}0.644 \\
(0.725)\end{array}$ & & $\begin{array}{l}2.509^{* * * *} \\
(0.968)\end{array}$ & & $\begin{array}{l}2.759^{* *} \\
(1.345)\end{array}$ \\
\hline Polity & & $\begin{array}{l}-0.102 \\
(0.048)\end{array}$ & & $\begin{array}{l}-0.109^{* * *} \\
(0.052)\end{array}$ & & $\begin{array}{l}-0.162^{* *} \\
(0.078)\end{array}$ & & $\begin{array}{l}-0.183 \\
(0.250)\end{array}$ \\
\hline Civil Law Dummy & & $\begin{array}{l}-1.060^{* * *} \\
(0.442)\end{array}$ & & $\begin{array}{l}-0.850 * \\
(0.446)\end{array}$ & & $\begin{array}{l}-1.378 " \\
(0.772)\end{array}$ & & $\begin{array}{l}-0.863 \\
(1.078)\end{array}$ \\
\hline Observations & 1839 & 1303 & 1839 & 1303 & 1839 & 1303 & 1839 & 1303 \\
\hline Number of Countries & 105 & 94 & 105 & 94 & 105 & 94 & 105 & 94 \\
\hline
\end{tabular}

The dependent variable is a reform dummy that takes the value one in years when the CBIS index increases in columns (1)-(4) and decreases in columns (5)-(8). Financial Crisis is a dummy variable that takes the value one if a country has experienced a systemic banking crisis in the previous two years. Increases/Reversals in CBIS (World/Continent) represent the share of countries that have increased/decreased the involvement of their central bank in financial sector supervision in the world/continent in the same year. Reforms in CBI is dummy for countries undertaking reforms that modified the degree of independence of their central banks in the same year. Government Change is dummy variable that indicates whether a change in government took place in the past two years. Polity captures the level of democracy of the country. Constant terms are included, but not reported. See Appendix Table A4 for complete variable definitions. Clustered standard errors in parentheses.

**** denotes significance at a $1 \%$ level.

** denotes significance at a $5 \%$ level.

" denotes significance at a $10 \%$ level.

crisis occurred in the two years prior to a reform year. We now include the reform year in this definition, to account for reforms and crises that happened simultaneously. As columns (5) and (6) show, the positive impact of the crisis variable is still present, although not as precisely estimated. This suggests that reforms generally occur after a banking crisis. Overall, the baseline results in Tables 1 and 2 provide a strong support for our two main hypotheses. Namely, they underline the strongly robust link between reforms that modify the involvement of central banks in financial sector supervision and the occurrence of financial crises. Second, we also provide robust evidence of spillover effects in the reform process. Regardless of the measure of peer countries employed, our finding reflect strong learning or converge among peer countries. These results complement recent work that looks at the consequences of the 2007 Global Financial Crisis on the practice of monetary policy. For example, Blinder et al. (2017) conduct an extensive survey among central bankers and find that both crisis and non-crisis hit countries have implemented macro-prudential policies. We show here that crisis countries were more likely to undertake reforms that modified the involvement of their central bank in supervision.

The regressions presented in Tables 1 and 2 pool together reforms that increase the degree of central bank involvement in supervision, with the ones that decrease the responsibilities of monetary policy authorities. This raises concerns as to whether the drivers of reforms identified are associated with changes towards higher or lower central bank involvement in unified supervision. Hence, in Table 3, we focus our attention on events that increase or decrease the degree of central bank involvement in financial sector supervision, separately. Columns (1)-(4) pertain to reforms that increase the CBIS index, while columns (5)-(8) look at its reversals. 
Table 4

Determinants of the degree of central banks involvement in financial sector supervision.

\begin{tabular}{|c|c|c|c|c|c|}
\hline & (1) & (2) & (3) & (4) & (5) \\
\hline Financial Crises (Cumulative) & $\begin{array}{l}0.796^{* * * *} \\
(0.146)\end{array}$ & $\begin{array}{l}0.700^{* * * *} \\
(0.147)\end{array}$ & $\begin{array}{l}0.764^{\text {*******}} \\
(0.148)\end{array}$ & $\begin{array}{l}0.675^{* * *} \\
(0.149)\end{array}$ & $\begin{array}{l}0.027 \\
(0.232)\end{array}$ \\
\hline Central Bank Independence & $\begin{array}{l}-1.863^{* * *} \\
(0.530)\end{array}$ & $\begin{array}{l}-1.660^{* * * * *} \\
(0.549)\end{array}$ & $\begin{array}{l}-0.968^{* *} \\
(0.448)\end{array}$ & $\begin{array}{l}-0.627 \\
(0.466)\end{array}$ & $\begin{array}{l}0.255 \\
(0.823)\end{array}$ \\
\hline Governance & & $\begin{array}{l}-0.448^{*} \\
(0.262)\end{array}$ & & $\begin{array}{l}-0.332 \\
(0.261)\end{array}$ & $\begin{array}{l}0.031 \\
(0.205)\end{array}$ \\
\hline Civil Law Dummy & & $\begin{array}{l}-2.052^{* * * *} \\
(0.570)\end{array}$ & & $\begin{array}{l}-2.188^{* * * *} \\
(0.579)\end{array}$ & $\begin{array}{l}-0.829^{* * * *} \\
(0.310)\end{array}$ \\
\hline Latitude & & $\begin{array}{l}-0.047^{* * *} \\
(0.016)\end{array}$ & & $\begin{array}{l}-0.050^{* * *} \\
(0.017)\end{array}$ & $\begin{array}{l}-0.011 \\
(0.008)\end{array}$ \\
\hline Macroprudential Policies & & & & & $\begin{array}{l}0.212^{* * *} \\
(0.096)\end{array}$ \\
\hline Observations & 1409 & 1360 & 1495 & 1432 & 73 \\
\hline Number of Country & 93 & 93 & 93 & 93 & 73 \\
\hline Country FE & YES & & YES & & \\
\hline
\end{tabular}

The dependent variable is the CBIS index. Financial Crises (Cumulative) captures the cumulative number of financial crises since 1970. Central bank independence is a dynamic index computed following Grilli et al. (1991), columns (1)-(2) and (5), and Cukierman et al. (1992) in columns (3)-(4). Governance is the average value of the Worldwide Governance Indicators (WGI) from the World Bank. Macroprudential Policies is the share of macro-prudential policies controlled by the central bank, obtained from Cerutti et al. (2015). Constant terms are included, but not reported. Clustered standard errors in parentheses.

**** denotes significance at a $1 \%$ level.

** denotes significance at a $5 \%$ level.

* denotes significance at a $10 \%$ level.

Interestingly, financial crises have a positive and statistically significant impact on the probability of increasing the central bank involvement in financial supervision. However, when we look at reforms that decreased the supervisory powers of the central bank in columns (5)-(8), this impact is no longer statistically significant. These results show that financial crises are associated with reforms that generally increase central banks' supervisory responsibilities. The effects of the different bandwagon variables are still positive and strongly significant across all specifications. Therefore, peer effects are robust in explaining all types of reforms in financial supervisory architecture.

\subsection{Determinants of the degree of central banks involvement in financial sector supervision}

The results presented so far were only concerned with the drivers of the reform process in financial supervisory architecture. In this section we take advantage of the level of detail of the different types of supervision captured by the CBIS index. We now look at the determinants of a particular level of central bank involvement in financial sector supervision.

The dependent variable for this empirical strategy is therefore the level of $C B I S_{i t}$ index, which measures the degree of central bank involvement in supervision in country $i$ in year $t$. Given the discrete, ordinal nature of this index, the baseline estimation uses an ordered probit model which allows for multiple discrete outcomes to be ranked. We follow previous literature and consider a set of economic and geo-political elements as determinants of the level of the CBIS index (see also Dalla Pellegrina et al., 2013; Melecky and Podpiera, 2013). The baseline specification is as follows:

$$
C B I S_{i t}=\beta_{1} \text { Crises }_{i, t-1}+\beta_{2} C B I_{i, t-1}+\beta_{3}^{\prime} \mathbf{X}+\epsilon_{i t},
$$

where Crises is the cumulative count of financial crises that have occurred in a country between 1970 and year $t-1$; $C B I_{i, t-1}$ is degree of central bank independence (CBI) computed using the Grilli et al. (1991) (GMT) or the Cukierman et al. (1992) (CWN) indices; and $\mathbf{X}$ is a vector of additional control variables. ${ }^{12}$ At difference with the previous section, here we employ a cumulative measure of the crisis dummy, as past crises might have resulted in a persistently higher level of the CBIS index in future years. We also include lagged levels of the CBI index in this section, as part of the Grilli et al. (1991) index contains information on supervision as well. This was not an issue in the previous analysis, since we only considered reforms along the other dimensions of this index. Finally, it is worth noting that our approach differs from previous works such as Dalla Pellegrina et al. (2013), who look at the central bank involvement in banking supervision in 2010. We employ a panel data approach that investigates the determinants of a particular financial sector supervisory architecture, over the entire period 1996-2013.

We present our main results in Table 4. We find again that countries experiencing financial crises in the past are associated with a

\footnotetext{
${ }^{12}$ All explanatory variables considered are detailed in Table A4 in the appendix.
} 
higher central bank involvement in supervision. Furthermore, as our crisis dummy is now cumulative, the positive and strongly significant coefficient in columns (1)-(4) also implies that experiencing more than one crisis is associated with an even more supervisory roles for the central bank. We also find that higher central bank independence is associated with less involvement of the central bank in financial sector supervision. This result is stronger when we consider the dynamic evolution of the Grilli et al. (1991) index in columns (1) and (2), as compared to the Cukierman et al. (1992) index in columns (3) and (4). These findings support the idea that, the more independent a central bank is, the less likely politicians are to unify financial sector supervision in its hands, since they might fear bureaucratic misconduct. Among the other explanatory variables, we find that civil law and more Nordic countries tend to have financial supervision responsibilities outside the central bank.

Our focus in this paper has been on micro-prudential policies, as the regulatory framework our index captures is aimed at preventing the costly failure of individual financial institutions. However, the magnitude of the 2007 global financial crisis has draw attention to the need of financial supervision to take a macro-prudential direction and to safeguard the financial system as a whole. ${ }^{13}$ Given their complementary goals, one would expect that countries in which the central bank oversees more macro-prudential policies, will also be associated with more central bank involvement in financial sector supervision, as captured by our index. Blanchard (2015) argues that "is clear that central banks will end up with substantially more responsibilities - whether they are given in full or shared - for financial regulation, financial supervision, and the use of macro prudential tools." To test this hypothesis, we include an index of the share of macro-prudential policies controlled by the central bank in our model (4). We obtain this data from Cerutti et al. (2015), who compute the share of macro-prudential policies entrusted to the central bank in 2013. As this measure is only available in one year, but may change over time, the estimations in Column (5) of Table 4 are in a cross-sectional setting employing 2013 data for all variables. We find that countries in which more macro-prudential policies are entrusted to the central bank are also associated to a greater involvement of the central bank in the micro-prudential supervision of the entire financial sector. This suggests a tendency of these two regulatory frameworks to be assigned as a responsibility of central banks.

\subsection{Robustness checks}

This section provides a series of further robustness checks. First, we consider an alternative definition of our first set of bandwagon effects. Instead of looking at the share of countries reforming their supervisory architecture, we now consider the share of countries that have in place the same institutional setting as the reference country. This takes into account the fact that, if a certain supervisory architecture is "fashionable", countries are less likely to undertake reforms that modify it. This alternative methodology results in two new measures denoted by "Same CBIS Index (World)" and "Same CBIS Index (Continent)", which indicate the share of countries that are characterised by the same institutional setting as country $i$ in year $t$, all around the world and in the same continent, respectively. These variables can be interpreted as follows: if any spillover effects in the architecture of financial sector supervision are present, the probability that country $i$ undertakes a reform in year $t$ is negatively related with the share of countries that are currently adopting its same supervisory architecture (same CBIS). In other words, when the supervisory system of country $i$ is identical to the one of a substantial number of other countries, country $i$ is less likely to implement a reform that would modify it. The negative and statistically significant coefficient of the new measures of peer effects across all specifications in Appendix Table A5 supports this hypothesis. Hence, the more fashionable a supervisory architecture is, the less interested a country will be in implementing a reform to modify it. The different columns in Appendix Table A5 control for the same country characteristics as our estimations in Table 1.

In Appendix Table A6, we present some sensitivity tests regarding the drivers of positive versus negative reforms. In Table 3, we have considered only the first set of bandwagon effects, namely those related to the share of countries undertaking reforms. Hence, in Appendix Table A6, we re-estimate the complementary logarithmic model and look at the second set of spillover indicators which take into account the distance between the reference country and its geographical and trading peers, respectively. Results are highly robust and support the strong peer effects in undertaking reforms, in particular those that increase the level of CBIS.

Our next set of robustness tests refers to the type of crises that might trigger reforms in financial sector supervision. In our baseline results we have considered the impact of systemic banking crises only. We now check whether other types of crises might be associated with similar reforms. In particular, we consider the role of economic recessions or currency crises in the two years prior to a reform. Appendix Table A7 presents the same estimations as in Table 1 controlling for these other types of crises. We find no support for an effect of recessions or currency crises on the probability of reforming CBIS. Hence, only crises that originate in the banking sector trigger such reforms. ${ }^{14}$

To check the robustness of our second empirical strategy, we augment the model in Eq. (4) with a set of control variables employed in Melecky and Podpiera (2013). Melecky and Podpiera (2013) consider a larger set of institutional, economic, as well as financial characteristics, to explain financial sector supervision unification. Our results complement their findings since the more detailed structure of our index enables us to relate these country characteristics to the level of supervisory unification inside the central bank.

These new results are presented in Table 5, where we use the CBIS Index in columns (1) and (2) and a restricted version of this

\footnotetext{
${ }^{13}$ Macro-prudential policies include the use of several instruments such as loan-to-value and debt-to-income ratios, limits on credit growth, limits on foreign lending, reserve requirements, etc. (see Claessens et al., 2013; Cerutti et al., 2015).

${ }^{14}$ In unreported results, we perform several other robustness checks. We estimate the model that assesses the probability of reforming CBIS employing a probit model instead of the complementary logarithmic one. We also consider an alternative measure of central bank independence computed following Cukierman et al. (1992). Our main results hold under these alternative estimations and are available upon request.
} 
Table 5

Determinants of the degree of central banks involvement in financial sector supervision: Robustness checks.

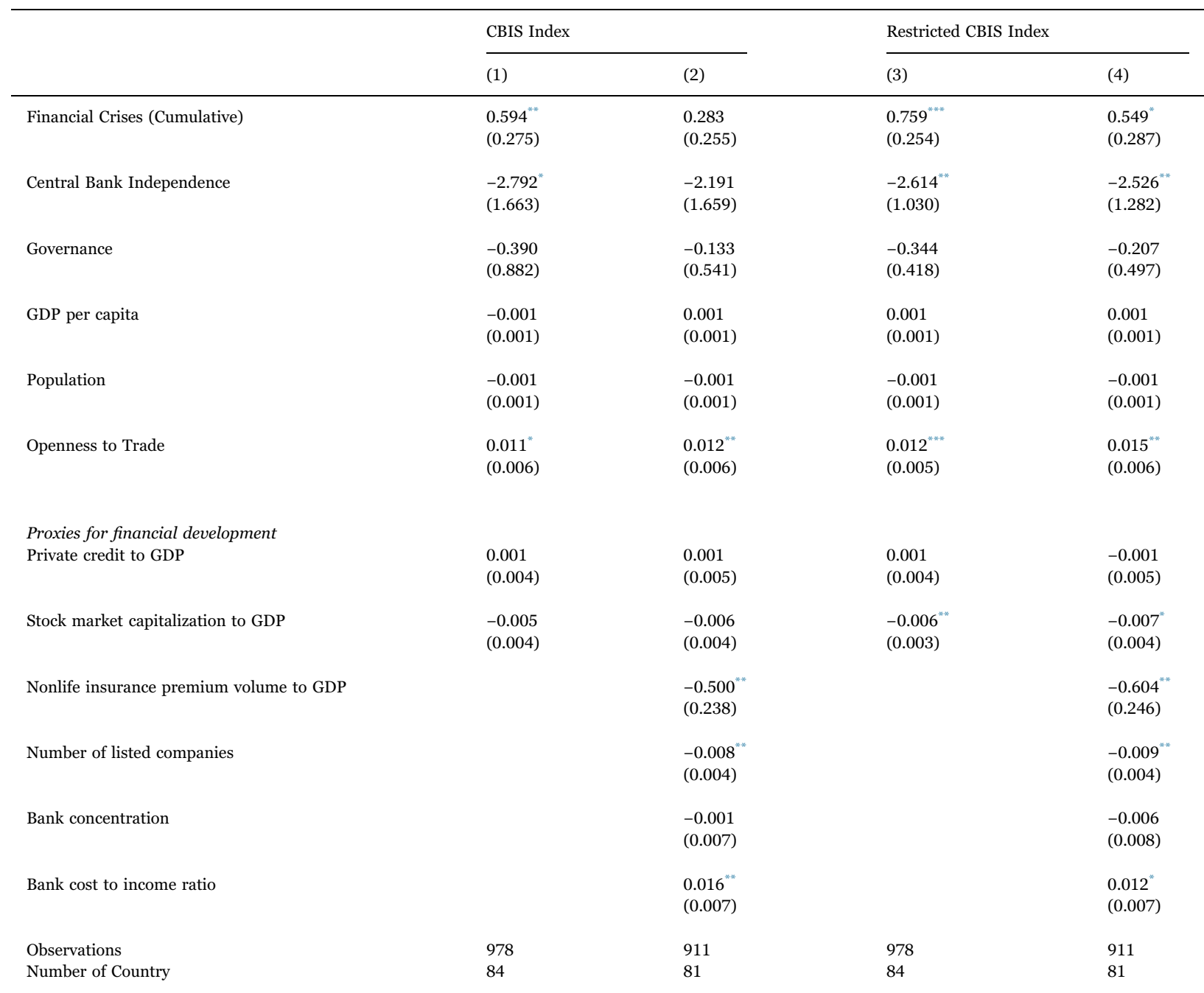

The dependent variable is the CBIS index in columns (1)-(2) and a restricted version of this index in columns (3)-(4). Financial Crises (Cumulative) captures the cumulative number of financial crises since 1970. Central Bank Independence is computed following the Grilli et al. (1991). Governance is the average value of the Worldwide Governance Indicators (WGI) from the World Bank. Openness to Trade is a measure of the country's degree of openness to trade. Private Credit to GDP, Nonlife insurance premium, Stock market capitalization to GDP, Number of listed companies, Bank concentration and Bank cost to income ratio are various proxies of financial development. See Appendix Table A4 for complete variable definitions. Clustered standard errors in parentheses.

**** denotes significance at a $1 \%$ level.

*** denotes significance at a $5 \%$ level.

* denotes significance at a $10 \%$ level.

index in columns (3) and (4). This latter index is a restricted version of our main measure and ranges from 1 to 4 . Same as before, higher values indicate a higher concentration of supervisory powers in the hands of the central bank. A value of 1 is assigned if the central bank has no responsibility for financial sector supervision, 2 if the central bank is the sole supervisor of the banking sector, 3 if the central bank has supervisory responsibility in (any) two sectors and 4 if the central bank is the sole institution responsible for supervision in the banking, insurance and securities markets sectors. This alternative aggregation and point ranking ensures us that our main results are not driven by the choice of the ordering of the different levels of supervisory integration.

Similar to the findings in Melecky and Podpiera (2013), we also find evidence that the degree of concentration of supervision in the hands of the central bank is influenced by: a cumulative index of past financial crises, the degree of central bank independence, openness and various proxies for each type of financial sector development: i.e. banks (Bank cost to income ratio), capital markets (Stock market capitalization ratio) and insurance (Insurance premium ratio). Apart from our baseline variables, results also suggest that smaller economies, which tend to also have a higher degree of openness to trade, are more likely to have fewer institutional authorities and thus integrate the supervision inside the central bank. Regarding the proxies for financial development, most results 
Table 6

Changes in the CBIS Index in a dynamic spatial panel estimation.

\begin{tabular}{|c|c|c|c|c|c|c|}
\hline & \multicolumn{3}{|c|}{ Level model: $C B I S_{i t}$} & \multicolumn{3}{|c|}{ Spatial first-difference } \\
\hline & & & & \multicolumn{3}{|l|}{$\Delta C B I S_{i t}$} \\
\hline & (1) & (2) & (3) & (4) & (5) & (6) \\
\hline $\mathrm{CBIS}_{t-1}$ & $\begin{array}{l}0.821^{* * * * *} \\
(0.024)\end{array}$ & $\begin{array}{l}0.819^{* * * *} \\
(0.024)\end{array}$ & $\begin{array}{l}0.819^{* * * *} \\
(0.024)\end{array}$ & $\begin{array}{l}0.043 \\
(0.036)\end{array}$ & $\begin{array}{l}0.042 \\
(0.036)\end{array}$ & $\begin{array}{l}0.042 \\
(0.036)\end{array}$ \\
\hline $\mathrm{W} \mathrm{CBIS}_{t}$ & $\begin{array}{l}0.33 \\
(0.326)\end{array}$ & $\begin{array}{l}0.304 \\
(0.326)\end{array}$ & $\begin{array}{l}0.311 \\
(0.329)\end{array}$ & $\begin{array}{l}0.084 \\
(0.332)\end{array}$ & $\begin{array}{l}0.073 \\
(0.332)\end{array}$ & $\begin{array}{l}0.075 \\
(0.335)\end{array}$ \\
\hline $\mathrm{W} \mathrm{CBIS}_{t-1}$ & $\begin{array}{l}-0.05 \\
(0.213)\end{array}$ & $\begin{array}{c}-0.018 \\
(0.211)\end{array}$ & $\begin{array}{l}-0.021 \\
(0.213)\end{array}$ & $\begin{array}{l}0.432 \\
(0.223)\end{array}$ & $\begin{array}{l}0.464 \\
(0.223)\end{array}$ & $\begin{array}{l}0.470 \\
(0.226)\end{array}$ \\
\hline Financial Crisis & $\begin{array}{l}0.075^{*} \\
(0.041)\end{array}$ & $\begin{array}{l}0.075^{*} \\
(0.041)\end{array}$ & $\begin{array}{l}0.075^{*} \\
(0.041)\end{array}$ & $\begin{array}{l}0.082^{*} \\
(0.043)\end{array}$ & $\begin{array}{l}0.081^{*} \\
(0.043)\end{array}$ & $\begin{array}{l}0.081^{*} \\
(0.043)\end{array}$ \\
\hline Governance & $\begin{array}{l}0.036 \\
(0.116)\end{array}$ & $\begin{array}{l}0.039 \\
(0.116)\end{array}$ & $\begin{array}{l}0.04 \\
(0.116)\end{array}$ & $\begin{array}{l}0.158 \\
(0.123)\end{array}$ & $\begin{array}{l}0.159 \\
(0.123)\end{array}$ & $\begin{array}{l}0.161 \\
(0.123)\end{array}$ \\
\hline OECD Member & $\begin{array}{l}0.001 \\
(0.157)\end{array}$ & $\begin{array}{l}-0.007 \\
(0.157)\end{array}$ & $\begin{array}{c}-0.011 \\
(0.158)\end{array}$ & $\begin{array}{l}0.055 \\
(0.169)\end{array}$ & $\begin{array}{l}0.047 \\
(0.169)\end{array}$ & $\begin{array}{l}0.045 \\
(0.170)\end{array}$ \\
\hline Observations & 975 & 975 & 975 & 975 & 975 & 975 \\
\hline Number of countries & 65 & 65 & 65 & 65 & 65 & 65 \\
\hline p-value of Wald-test & 0.747 & 0.736 & 0.729 & NR & NR & NR \\
\hline
\end{tabular}

The dependent variable is the $C B I S_{i t}$ index in columns (1)-(3) and $\Delta C B I S_{i t}$ in (4)-(6). W is a spatial weight matrix based on inverse distances with cut-off point at 2000 in columns (1) and (4); 3000 in columns (2) and (5) and $4000 \mathrm{~km}$ in columns (3) and (6), respectively. Peer effects variables in columns (4)-(6) are in first difference. Time dummies are included. Standard errors in parentheses. NR $=$ not relevant.

**** denotes significance at a $1 \%$ level.

** denotes significance at a $5 \%$ level.

* denotes significance at a $10 \%$ level.

suggest that more financially developed countries are characterized by a lower concentration of supervisory powers in the hands of the central bank. This implies that, in countries with very large financial sectors, the task of supervision becomes more complex and is less likely to be unified in the hand of the central bank. Lastly, note that there is largely no difference between the estimations employing the restricted or the full index, which mitigates concerns regarding any subjectivity in the construction of our index.

The last robustness check performed considers an alternative econometric approach to our baseline investigation of the drivers of reforms in CBIS. Our empirical analysis has been focused on the probability of changing the supervisory framework with no considerations on the magnitude of these changes. This is motivated by the fact that the size and direction of a change in CBIS do not have an economic interpretation, as there is no a priori optimal level of central bank involvement in supervision. Nonetheless, an alternative model is to look at the changes in the level of the index over time, i.e. $\Delta C B I S_{i t}$. Given that our goal is to look at an international convergence in institutional framework among countries, we employ the dynamic spatial panel data model proposed in Elhorst et al. (2013). They look at the spatial spillover effects of financial liberalization reforms employing an index developed by Abiad and Mody (2005).

Importantly, they also show that prior to testing for peer effects, one must first test whether indices are spatially cointegrated, as countries tend to follow similar trends in reforming their institutional setting. We thus follow their approach and test for the stability of the system, through a joint test on the coefficients of the lagged dependent variable and those of the peer effects proxies. The $p$ value of these tests is shown in Table 6, columns (1)-(3). Columns (1)-(3) also use different definitions for the geographical peers matrix, based on inverse distances with cut-off point at 2000; 3000 and $4000 \mathrm{~km}$, respectively. A rejection of the null hypothesis of the joint test of the coefficients implies the presence of a spatial unit root, and, in order to obtain consistent estimates, a firstdifference model needs to be estimated. After confirming the spatial cointegration among peer countries, we proceed to estimating a first difference model in column (4)-(6). The results under this more demanding econometric setting confirm our initial findings. The positive and significant coefficient of the lagged spatial effects, $W C B I S_{t-1}$, indicates that an increase in the CBIS index in the previous period among geographical peers is associated with a reform that increases the involvement of the central bank in supervision. This result is consistent regardless of the definition of the peer matrix. Moreover, the effect of the crisis is still significant. 


\section{Concluding remarks}

The role of central banks in the supervision of the financial sector has received a lot of attention following the 2007-09 Global Financial Crisis. It is generally argued that crises episodes signal possible supervisory failures of the institutional architecture of financial sector supervision. However, no previous study explicitly tests whether the occurrence of financial crises is associated with reforms in the architecture of financial sector supervision.

In this paper, we propose a novel investigation of the determinants of reforms that shape the involvement of central banks in financial sector supervision. We use a new dataset that tracks the evolution of reforms in the supervisory architecture of the financial sector including banking, insurance and securities markets. We build an index that measures the degree to which the supervision of the entire financial sector is concentrated in the hands of the central bank.

Employing a panel of 105 countries, over the period 1996-2013, we find that, systemic banking crises are important drivers of reforms in supervisory architecture. More importantly, crises are associated with reforms that increase the involvement of the central bank in the supervision of the entire financial sectors, but not with reforms that decrease it. At the same time, we also highlight an important international spillover effect among central banks. We propose several measures to capture the effect of peer countries on the probability of reforming one's institutional setting. We show that countries are more likely to reform when the share of countries undertaking reforms in the same period is higher. We also construct two measures of peer countries employing spatial characteristics of countries such as geographical distance and trade relationships. We find that countries whose institutional setting is the farthest from their peer group are more likely to undertake reforms. Finally, a country is less likely to change its supervisory architecture if this architecture is popular among its peers. These results contribute to a recent literature that tries to understand the role of international spillovers in shaping the institutional design among countries.

While our research highlights important determinants of the probability of reforms in financial supervision, we do not take a stand on whether a higher degree of central bank involvement in supervision might influence the stability or efficiency of the financial sector. Employing our new index of financial supervisory architecture, future research could be directed towards understanding the macroeconomic effects of moving towards a unified supervision inside the central bank.

\section{Acknowledgements}

We would like to thank Georgios Chortareas, Etienne Farvaque, Oana Peia, the Editor Jan-Egbert Sturm, two anonymous referees and seminar participants at King's College London, Central Bank of Ireland, the 2017 ASSA Annual Meeting, the 2016 Workshop on Financial Stability at Banco Central del Uruguay, the 18th T2M Annual Conference, the 7th IFABS International Conference, Paris School of Economics, University of Lille, for their helpful comments and suggestions.

\section{Appendix}

See Tables A1-A7 .

Table A1

Analyzed countries.

\begin{tabular}{|c|c|c|c|c|c|}
\hline Country & First Year & Last Year & Country & First Year & Last Year \\
\hline Afghanistan & 2005 & 2013 & Kosovo & 2008 & 2013 \\
\hline Albania & 1996 & 2013 & Kuwait & 2011 & 2013 \\
\hline Algeria & 1996 & 2013 & Latvia & 1996 & 2013 \\
\hline Argentina & 1996 & 2013 & Lebanon & 2011 & 2013 \\
\hline Armenia & 2000 & 2013 & Lithuania & 1996 & 2013 \\
\hline Australia & 1996 & 2013 & Luxembourg & 1996 & 2013 \\
\hline Austria & 1996 & 2013 & Macedonia & 2009 & 2013 \\
\hline Azerbaijan & 2007 & 2013 & Malaysia & 1996 & 2013 \\
\hline Bahrain & 1996 & 2013 & Malta & 1996 & 2013 \\
\hline Bangladesh & 1996 & 2013 & Mauritius & 2001 & 2013 \\
\hline Barbados & 1996 & 2013 & Mexico & 1996 & 2013 \\
\hline Belarus & 1996 & 2013 & Moldova & 1998 & 2013 \\
\hline Belgium & 1996 & 2013 & Mongolia & 2006 & 2013 \\
\hline Bermuda & 1996 & 2013 & Montenegro & 2007 & 2013 \\
\hline Bolivia & 1996 & 2013 & Morocco & 2002 & 2013 \\
\hline Bosnia and Herzegovina & 2004 & 2013 & Namibia & 2001 & 2013 \\
\hline Botswana & 1996 & 2013 & Netherlands & 1996 & 2013 \\
\hline Brazil & 1996 & 2013 & New Zealand & 1996 & 2013 \\
\hline Bulgaria & 1997 & 2013 & Nicaragua & 1996 & 2013 \\
\hline Canada & 1996 & 2013 & Norway & 1996 & 2013 \\
\hline
\end{tabular}


Table A1 (continued)

\begin{tabular}{|c|c|c|c|c|c|}
\hline Country & First Year & Last Year & Country & First Year & Last Year \\
\hline Chile & 1996 & 2013 & Pakistan & 1997 & 2013 \\
\hline China & 1998 & 2013 & Panama & 1996 & 2013 \\
\hline Colombia & 1996 & 2013 & Peru & 1996 & 2013 \\
\hline Costa Rica & 1996 & 2013 & Philippines & 1996 & 2013 \\
\hline Croatia & 1996 & 2013 & Poland & 1996 & 2013 \\
\hline Cyprus & 2002 & 2013 & Portugal & 1996 & 2013 \\
\hline Czech Republic & 1996 & 2013 & Qatar & 2005 & 2013 \\
\hline Denmark & 1996 & 2013 & Republic of Serbia & 2003 & 2013 \\
\hline Dominican Republic & 2000 & 2013 & Romania & 2002 & 2013 \\
\hline Ecuador & 1996 & 2013 & Russia & 1996 & 2013 \\
\hline Egypt & 1996 & 2013 & Saudi Arabia & 1996 & 2013 \\
\hline El Salvador & 1996 & 2013 & Singapore & 1996 & 2013 \\
\hline Estonia & 1996 & 2013 & Slovakia & 2000 & 2013 \\
\hline Finland & 1996 & 2013 & Slovenia & 2000 & 2013 \\
\hline France & 1996 & 2013 & South Africa & 1996 & 2013 \\
\hline Georgia & 1999 & 2013 & South Korea & 1996 & 2013 \\
\hline Germany & 1996 & 2013 & Spain & 1996 & 2013 \\
\hline Greece & 1996 & 2013 & Sri Lanka & 2000 & 2013 \\
\hline Guatemala & 2002 & 2013 & Sweden & 1996 & 2013 \\
\hline Hong Kong S.A.R. & 1996 & 2013 & Switzerland & 1996 & 2013 \\
\hline Hungary & 1996 & 2013 & Thailand & 1996 & 2013 \\
\hline Iceland & 1999 & 2013 & The Bahamas & 1996 & 2013 \\
\hline India & 1999 & 2013 & Trinidad and Tobago & 1996 & 2013 \\
\hline Indonesia & 1996 & 2013 & Tunisia & 1996 & 2013 \\
\hline Iran & 2000 & 2013 & Turkey & 1996 & 2013 \\
\hline Ireland & 1996 & 2013 & Ukraine & 2003 & 2013 \\
\hline Israel & 1996 & 2013 & United Arab Emirates & 2000 & 2013 \\
\hline Italy & 1996 & 2013 & United Kingdom & 1996 & 2013 \\
\hline Jamaica & 1996 & 2013 & United States of America & 1996 & 2013 \\
\hline Japan & 1996 & 2013 & Uruguay & 1996 & 2013 \\
\hline Jordan & 1999 & 2013 & Venezuela & 1996 & 2013 \\
\hline Kazakhstan & 1998 & 2013 & Zimbabwe & 2004 & 2013 \\
\hline Kenya & 1996 & 2013 & & & \\
\hline
\end{tabular}

Table A2

Supervisory Authorities in 105 countries as of end 2013.

\begin{tabular}{|c|c|c|c|c|c|c|c|}
\hline Country & $\begin{array}{l}\text { Banking } \\
\text { Sector }\end{array}$ & $\begin{array}{l}\text { Insurance } \\
\text { Sector }\end{array}$ & $\begin{array}{l}\text { Securities } \\
\text { Markets }\end{array}$ & Country & $\begin{array}{l}\text { Banking } \\
\text { Sector }\end{array}$ & $\begin{array}{l}\text { Insurance } \\
\text { Sector }\end{array}$ & $\begin{array}{l}\text { Securities } \\
\text { Markets }\end{array}$ \\
\hline Afghanistan & $\mathrm{CB}$ & I & $\mathrm{CB}$ & Kosovo & $\mathrm{CB}$ & $\mathrm{CB}$ & $\mathrm{CB}$ \\
\hline Albania & $\mathrm{CB}$ & IS & IS & Kuwait & $\mathrm{CB}$ & G & S \\
\hline Algeria & $\mathrm{CB}$ & I & $\mathrm{S}$ & Latvia & $\mathrm{U}$ & $\mathrm{U}$ & $\mathrm{U}$ \\
\hline Argentina & $\mathrm{CB}$ & I & $\mathrm{S}$ & Lebanon & $\mathrm{CB}, \mathrm{B}$ & I & $\mathrm{S}$ \\
\hline Armenia & $\mathrm{CB}$ & $\mathrm{CB}$ & $\mathrm{CB}$ & Lithuania & $\mathrm{CB}$ & $\mathrm{CB}$ & $\mathrm{CB}$ \\
\hline Australia & BI & $\mathrm{BI}$ & $\mathrm{S}$ & Luxembourg & BS & I & BS \\
\hline Austria & $\mathrm{CB}, \mathrm{U}$ & $\mathrm{U}$ & $\mathrm{U}$ & Macedonia & $\mathrm{CB}$ & I & $\mathrm{S}$ \\
\hline Azerbaijan & $\mathrm{CB}$ & I & $\mathrm{S}$ & Malaysia & $\mathrm{CB}, \mathrm{G}$ & $\mathrm{CB}, \mathrm{G}$ & $\mathrm{S}$ \\
\hline Bahrain & $\mathrm{CB}$ & $\mathrm{CB}$ & $\mathrm{CB}$ & Malta & $\mathrm{U}$ & $\mathrm{U}$ & $\mathrm{U}$ \\
\hline Bangladesh & $\mathrm{CB}$ & I & $\mathrm{S}$ & Mauritius & $\mathrm{CB}$ & IS & IS \\
\hline Barbados & $\mathrm{CB}$ & IS & IS & Mexico & BS & I & BS \\
\hline Belarus & $\mathrm{CB}$ & $\mathrm{G}$ & $\mathrm{G}$ & Moldova & $\mathrm{CB}$ & IS & IS \\
\hline Belgium & $\mathrm{CB}$ & $\mathrm{CB}$ & $\mathrm{CB}$ & Mongolia & $\mathrm{CB}$ & IS & IS \\
\hline Bermuda & $\mathrm{CB}$ & $\mathrm{CB}$ & $\mathrm{CB}$ & Montenegro & $\mathrm{CB}$ & I & $\mathrm{S}$ \\
\hline Bolivia & B & IS & IS & Morocco & $\mathrm{CB}$ & $\mathrm{G}$ & $\mathrm{S}$ \\
\hline Bosnia and Herzegovina & $\mathrm{CB}, \mathrm{B}^{* *}$ & I & $\mathrm{S}$ & Namibia & $\mathrm{CB}$ & IS & IS \\
\hline Botswana & $\mathrm{CB}$ & $\mathrm{G}$ & G & Netherlands & $\mathrm{CB}$ & $\mathrm{CB}$ & $\mathrm{CB}$ \\
\hline Brazil & $\mathrm{CB}$ & I & $\mathrm{S}$ & New Zealand & $\mathrm{CB}$ & $\mathrm{CB}$ & $\mathrm{S}$ \\
\hline Bulgaria & $\mathrm{CB}$ & IS & IS & Nicaragua & $\mathrm{U}$ & $\mathrm{U}$ & $\mathrm{U}$ \\
\hline Canada & BI & BI & $\mathrm{S}^{* *}$ & Norway & $\mathrm{U}$ & $\mathrm{U}$ & $\mathrm{U}$ \\
\hline Chile & $\mathrm{CB}, \mathrm{U}$ & $\mathrm{U}$ & $\mathrm{U}$ & Pakistan & $\mathrm{CB}$ & IS & IS \\
\hline China & $\mathrm{B}$ & I & $\mathrm{S}$ & Panama & B & I & $\mathrm{S}$ \\
\hline Colombia & $\mathrm{U}$ & $\mathrm{U}$ & $\mathrm{U}$ & Peru & $\mathrm{U}$ & $\mathrm{U}$ & $\mathrm{U}$ \\
\hline Costa Rica & $\mathrm{B}$ & I & $\mathrm{S}$ & Philippines & $\mathrm{CB}$ & I & $\mathrm{S}$ \\
\hline Croatia & $\mathrm{CB}$ & IS & IS & Poland & $\mathrm{U}$ & $\mathrm{U}$ & $\mathrm{U}$ \\
\hline
\end{tabular}


Table A2 (continued)

\begin{tabular}{|c|c|c|c|c|c|c|c|}
\hline Country & $\begin{array}{l}\text { Banking } \\
\text { Sector }\end{array}$ & $\begin{array}{l}\text { Insurance } \\
\text { Sector }\end{array}$ & $\begin{array}{l}\text { Securities } \\
\text { Markets }\end{array}$ & Country & $\begin{array}{l}\text { Banking } \\
\text { Sector }\end{array}$ & $\begin{array}{l}\text { Insurance } \\
\text { Sector }\end{array}$ & $\begin{array}{l}\text { Securities } \\
\text { Markets }\end{array}$ \\
\hline Cyprus & $\mathrm{CB}$ & I & S & Portugal & $\mathrm{CB}$ & I & $\mathrm{S}$ \\
\hline Czech Republic & $\mathrm{CB}$ & $\mathrm{CB}$ & $\mathrm{CB}$ & Qatar & $\mathrm{CB}$ & $\mathrm{CB}$ & $\mathrm{CB}$ \\
\hline Denmark & $\mathrm{U}$ & $\mathrm{U}$ & $\mathrm{U}$ & Republic of Serbia & $\mathrm{CB}$ & $\mathrm{CB}$ & $\mathrm{S}$ \\
\hline Dominican Republic & $\mathrm{B}$ & I & S & Romania & $\mathrm{CB}$ & IS & IS \\
\hline Ecuador & $\mathrm{BI}$ & $\mathrm{BI}$ & S & Russia & $\mathrm{CB}$ & $\mathrm{CB}$ & $\mathrm{CB}$ \\
\hline Egypt & $\mathrm{CB}$ & IS & IS & Saudi Arabia & $\mathrm{CB}$ & $\mathrm{CB}$ & $\mathrm{S}$ \\
\hline El Salvador & $\mathrm{U}$ & $\mathrm{U}$ & $\mathrm{U}$ & Singapore & $\mathrm{CB}$ & $\mathrm{CB}$ & $\mathrm{CB}$ \\
\hline Estonia & $\mathrm{U}$ & $\mathrm{U}$ & $\mathrm{U}$ & Slovakia & $\mathrm{CB}$ & $\mathrm{CB}$ & $\mathrm{CB}$ \\
\hline Finland & $\mathrm{U}$ & $\mathrm{U}$ & $\mathrm{U}$ & Slovenia & $\mathrm{CB}$ & I & S \\
\hline France & $\mathrm{CB}$ & $\mathrm{CB}$ & S & South Africa & $\mathrm{CB}$ & IS & IS \\
\hline Georgia & $\mathrm{CB}$ & I & $\mathrm{CB}$ & South Korea & $\mathrm{U}$ & $\mathrm{U}$ & $\mathrm{U}$ \\
\hline Germany & $\mathrm{CB}, \mathrm{U}$ & $\mathrm{U}$ & $\mathrm{U}$ & Spain & $\mathrm{CB}$ & I & $\mathrm{S}$ \\
\hline Greece & $\mathrm{CB}$ & $\mathrm{CB}$ & $\mathrm{S}$ & Sri Lanka & $\mathrm{CB}$ & I & $\mathrm{S}$ \\
\hline Guatemala & BI & BI & $\mathrm{S}$ & Sweden & $\mathrm{U}$ & $\mathrm{U}$ & $\mathrm{U}$ \\
\hline Hong Kong S.A.R. & $\mathrm{CB}$ & I & $\mathrm{S}$ & Switzerland & $\mathrm{U}$ & $\mathrm{U}$ & $\mathrm{U}$ \\
\hline Hungary & $\mathrm{CB}$ & $\mathrm{CB}$ & $\mathrm{CB}$ & Thailand & $\mathrm{CB}$ & I & $\mathrm{S}$ \\
\hline Iceland & $\mathrm{U}$ & $\mathrm{U}$ & $\mathrm{U}$ & The Bahamas & $\mathrm{CB}$ & $\mathrm{G}$ & $\mathrm{S}$ \\
\hline India & $\mathrm{CB}$ & I & $\mathrm{S}$ & Trinidad and Tobago & $\mathrm{CB}$ & $\mathrm{CB}$ & $\mathrm{S}$ \\
\hline Indonesia & $\mathrm{U}$ & $\mathrm{U}$ & $\mathrm{U}$ & Tunisia & $\mathrm{CB}$ & I & $\mathrm{S}$ \\
\hline Iran & $\mathrm{CB}$ & I & SS & Turkey & B & I & $\mathrm{S}$ \\
\hline Ireland & $\mathrm{CB}$ & $\mathrm{CB}$ & $\mathrm{CB}$ & Ukraine & $\mathrm{CB}$ & IS & IS \\
\hline Israel & $\mathrm{CB}$ & G & S & United Arab Emirates & $\mathrm{CB}$ & $\mathrm{CB}$ & $\mathrm{S}$ \\
\hline Italy & $\mathrm{CB}$ & $\mathrm{CB}$ & $\mathrm{S}$ & United Kingdom & $\mathrm{CB}$ & $\mathrm{CB}$ & $\mathrm{CB}$ \\
\hline Jamaica & $\mathrm{CB}$ & IS & IS & United States of America & $\mathrm{CB}, \mathrm{B}^{* * *}$ & $\mathrm{CB}, \mathrm{I}^{* *}$ & $\mathrm{~S}^{* * *}$ \\
\hline Japan & $\mathrm{U}$ & $\mathrm{U}$ & $\mathrm{U}$ & Uruguay & $\mathrm{CB}$ & $\mathrm{CB}$ & $\mathrm{CB}$ \\
\hline Jordan & $\mathrm{CB}$ & $\mathrm{G}$ & I & Venezuela & B & I & S \\
\hline Kazakhstan & $\mathrm{CB}$ & $\mathrm{CB}$ & $\mathrm{CB}$ & Zimbabwe & $\mathrm{CB}$ & I & $\mathrm{S}$ \\
\hline Kenya & $\mathrm{CB}$ & I & S & & & & \\
\hline
\end{tabular}

Notes: The initials have the following meaning: $\mathrm{B}=$ authority specialised in the banking sector; $\mathrm{BI}=$ authority specialised in the banking and insurance sector; $\mathrm{BS}=$ authority specialised in the banking sector and securities markets; $\mathrm{CB}=$ central bank; $\mathrm{G}=$ government; $\mathrm{I}=$ authority specialised in the insurance sector; IS = authority specialised in the insurance sector and securities markets; $\mathrm{S}=$ authority specialised in the securities markets; $\mathrm{U}=$ single authority for all sectors; ${ }^{* *}=$ state or regional agencies.

Table A3

Countries reforming Financial Sector Supervision between 1996 and 2013.

\begin{tabular}{|c|c|}
\hline Year & Countries \\
\hline \multicolumn{2}{|l|}{1996} \\
\hline \multicolumn{2}{|l|}{1997} \\
\hline 1998 & Australia, Japan, Luxembourg, United Kingdom \\
\hline 1999 & South Korea \\
\hline \multicolumn{2}{|l|}{2000} \\
\hline 2001 & Ireland, Latvia \\
\hline 2002 & Bahrain, Estonia, Malta \\
\hline 2003 & China, Kazakhstan, Saudi Arabia \\
\hline 2004 & Kazakhstan, Netherlands, Saudi Arabia, Trinidad and Tobago \\
\hline \multicolumn{2}{|l|}{2005} \\
\hline 2006 & Armenia, Czech Republic, Slovakia \\
\hline \multicolumn{2}{|l|}{2007} \\
\hline 2008 & Austria, Georgia, Poland \\
\hline 2009 & Georgia \\
\hline 2010 & France, Greece, Ireland, New Zealand, United States \\
\hline 2011 & Kazakhstan \\
\hline 2012 & Lithuania, United Kingdom \\
\hline 2013 & Georgia, Hungary, Indonesia, Italy, Qatar, Russia \\
\hline
\end{tabular}


Table A4

Data description.

\begin{tabular}{|c|c|c|}
\hline Variable & Definition & Description \\
\hline \multicolumn{3}{|l|}{ Dependent variables } \\
\hline CBIS Reform & Reforms in the degree of CBIS & $\begin{array}{l}\text { Dummy that signals whether a supervisory reform that modified } \\
\text { the CBIS Index have occurred or not in year } t \text {. }\end{array}$ \\
\hline CBIS Index & $\begin{array}{l}\text { Central Bank Involvement in } \\
\text { Supervision Index }\end{array}$ & $\begin{array}{l}\text { The CBIS Index ranges from } 1 \text { to } 6 \text {. A higher value indicates a } \\
\text { higher concentration of supervisory powers in the hand of the } \\
\text { central bank. The variable takes value }=6 \text { if the central bank has } \\
\text { full responsibilities for the supervision of the entire financial } \\
\text { system, }=5 \text { if banking and securities market supervision are in the } \\
\text { hand of the central bank, }=4 \text { if banking and insurance sector } \\
\text { supervision are in the hand of the central bank, }=3 \text { if the central } \\
\text { bank is only responsible for banking supervision, }=2 \text { if the central } \\
\text { bank is partially responsible for banking supervision, }=1 \text { if the } \\
\text { central bank is not involved in supervision. }\end{array}$ \\
\hline CBIS Restricted Index & Restricted CBIS & $\begin{array}{l}\text { This index is a restricted version of the CBIS Index and it ranges } \\
\text { from } 1 \text { to } 4 \text {. A higher value indicates a higher concentration of } \\
\text { supervisory powers in the hand of the central banks. The variable } \\
\text { takes value }=4 \text { if the central bank has full responsibilities for the } \\
\text { supervision of the entire financial system, }=3 \text { if the central bank } \\
\text { has supervisory responsibility in any two sectors, }=2 \text { if the central } \\
\text { bank has the main (or sole) responsibility for banking supervision, } \\
=1 \text { if the central bank is not involved in supervision. }\end{array}$ \\
\hline
\end{tabular}

\section{Independent variables}

Financial Crisis

Reforms in CBIS (World)

Reforms in CBIS

(Continent)

Peers - Geographical

Peers - Trade

CBI reform (GMT)

CBI Index

Same CBIS (World)

Same CBIS (Continent)

Financial Crisis

(Cumulative)

Other explanatory variables

Government Change

Governance

Powe

Worldwide Governance Indicators

OECD Dummy

OECD Membership Dummy

Proxy for Peer Effects

Proxy for Peer Effects

Proxy for Peer Effects

Proxy for Peer Effects

Central Bank Independence Legislative Reforms Independence

Proxy for Peer Effects

Proxy for Peer Effects

Cumulative number of Systemic Banking Crises
Systemic Banking Crises Dummy

Index of Central Bank Effective Changes in the Executive

Dummy that signals whether the effective control of executive power have changed up to two years before or not.

Dummy that signals whether a crisis have occurred in the previous two years.

Share of countries that are undertaking a financial sector supervisory reform in year $t$.

Share of countries that, located in the same continent as country $i$, are undertaking a financial supervisory reform in year $t$.

Peers - Geographical indicates the absolute distance between a country's level of CBIS and that of its peers, where the average value of CBIS of peer countries is computed based on geographical distance.

Peers - Trade indicates the absolute distance between a country's level of CBIS and that of its peers, where the average value of CBIS of peer countries is computed based on trade values.

Dummy that signals whether a central bank legislative reform that modified the Grilli et al. (1991) index of central bank

independence took place in year $t$. Given that this index also provides information on the involvement of central banks in banking supervision, the dummy variable for legislative reforms takes the value one only in years in which changes in the other characteristics of central bank institutional design took place.

Captures the degree of central bank independence as measured using the Grilli et al. (1991) (GMT) or the Cukierman et al. (1992) (CWN) index, respectively.

Contains the number of countries that are adopting the same

financial supervision architecture as country $i$ in year $t$.

Contains the number of countries that are located in the same continent as country $i$ and are adopting the same financial supervision architecture as country $i$ in year $t$.

Cumulative number of financial crises since 1970.

Source

Authors

Authors

Authors

Authors

Authors

Authors

Authors

Authors

Romelli (2016)

Romelli (2016)

Authors

Authors

Authors

Kaufmann et al. (2010)

Captures perceptions of the quality of public services, the quality of the civil service and the degree of its independence from political pressures, the quality of policy formulation and implementation, and the credibility of the government's commitment to such policies.

Dummy for OECD member countries: $1=$ OECD member; $0=$ non-OECD member.
(2010)

Authors
Kaufmann et al. 
Table A4 (continued)

\begin{tabular}{|c|c|c|c|}
\hline Variable & Definition & Description & Source \\
\hline Polity & Polity2 & $\begin{array}{l}\text { Index that measures the difference between the democratic and } \\
\text { the autocratic score of a country. The resulting unified polity scale } \\
\text { ranges from }+10 \text { (strongly democratic) to }-10 \text { (strongly } \\
\text { autocratic). }\end{array}$ & PolityIV (2014) \\
\hline Civil Law Dummy & Civil Law Legal Origins & $\begin{array}{l}\text { Dummy for Civil Law legal roots: } 1=\text { French, German and } \\
\text { Scandinavian Law; } 0=\text { non-French, German and Scandinavian } \\
\text { Law. }\end{array}$ & $\begin{array}{l}\text { La Porta et al. } \\
\text { (1999) }\end{array}$ \\
\hline Latitude & Countries' Latitude & $\begin{array}{l}\text { The value is calculated as in Beck et al. (1999) as absolute value of } \\
\text { country's latitude standardized on values between } 0 \text { and } 1 .\end{array}$ & $\begin{array}{l}\text { Mayer and Zignago } \\
\text { (2011) }\end{array}$ \\
\hline $\begin{array}{l}\text { Macroprudential Index } \\
\quad \text { (MPI) }\end{array}$ & $\begin{array}{l}\text { Index of central bank oversight of } \\
\text { macroprudential policies }\end{array}$ & $\begin{array}{l}\text { This index captures the degree of central bank oversight of } \\
\text { macroprudential policies. It is obtained by interacting the fraction } \\
\text { of macroprudential instruments that are controlled by the central } \\
\text { bank in } 2013 \text { and the sum of the } 12 \text { macroprudential instruments } \\
\text { included in the Global Macroprudential Policy Instruments } \\
\text { (GMPI) survey of the IMF. }\end{array}$ & Cerutti et al. (2015) \\
\hline Continents & Continents' Dummies & $\begin{array}{l}\text { Dummy that signals whenever a country is located in the Africa, } \\
\text { America, Asia, Europe or Oceania. }\end{array}$ & $\begin{array}{l}\text { Mayer and Zignago } \\
\text { (2011) }\end{array}$ \\
\hline GDP per capita & Real GDP per capita & GDP per capita at constant 2005 US\$. & World Bank (2014) \\
\hline Population & Population & $\begin{array}{l}\text { Total population of the country. The values shown are midyear } \\
\text { estimates. }\end{array}$ & World Bank (2014) \\
\hline Openness to Trade & Degree of Trade Openness & Exports + Imports of goods and services (\% of GDP). & World Bank (2014) \\
\hline Private credit to GDP & Private credit to GDP & Private credit by deposit money banks to GDP. & Čihák et al. (2013) \\
\hline Non life premium to GDP & Non life premium volume to GDP & Non life insurance premium volume as a share of GDP. & Čihák et al. (2013) \\
\hline $\begin{array}{l}\text { Stock market capitalization } \\
\text { to GDP }\end{array}$ & Stock market capitalization to GDP & Value of listed shares to GDP. & Čihák et al. (2013) \\
\hline Number of listed companies & Number of listed companies & Number of publicly listed companies per $10 \mathrm{~K}$ population. & Čihák et al. (2013) \\
\hline Bank Concentration & Banking sector concentration & $\begin{array}{l}\text { Assets of three largest banks as a share of assets of all commercial } \\
\text { banks. }\end{array}$ & Čihák et al. (2013) \\
\hline Bank cost to income ratio & $\begin{array}{l}\text { Commercial banks cost to income } \\
\text { ratio }\end{array}$ & Total costs as a share of total income of all commercial banks. & Čihák et al. (2013) \\
\hline
\end{tabular}

Table A5

determinants of supervisory reforms (Peer effects = same system).

\begin{tabular}{|c|c|c|c|c|c|c|}
\hline & (1) & (2) & (3) & (4) & (5) & (6) \\
\hline Financial Crisis & $\begin{array}{l}0.701^{* * *} \\
(0.343)\end{array}$ & $\begin{array}{l}0.688^{*} \\
(0.397)\end{array}$ & $\begin{array}{l}0.624^{*} \\
(0.338)\end{array}$ & $\begin{array}{l}0.538 \\
(0.382)\end{array}$ & $\begin{array}{l}1.234^{* * *} \\
(0.619)\end{array}$ & $\begin{array}{l}0.928 \\
(0.593)\end{array}$ \\
\hline Same CBIS Index (World) & $\begin{array}{l}-6.820 \\
(0.919)\end{array}$ & $\begin{array}{l}-7.237^{* * * *} \\
(1.286)\end{array}$ & & & $\begin{array}{l}-9.249^{* * * *} \\
(2.145)\end{array}$ & \\
\hline Same CBIS Index (Continent) & & & $\begin{array}{l}-5.745^{* * * *} \\
(1.094)\end{array}$ & $\begin{array}{l}-6.440 \\
(1.791)\end{array}$ & & $\begin{array}{l}-8.147^{* * * *} \\
(2.377)\end{array}$ \\
\hline CBI Reform (GMT) & & $\begin{array}{l}1.367^{* *} \\
(0.682)\end{array}$ & & $\begin{array}{l}1.328^{* * *} \\
(0.673)\end{array}$ & $\begin{array}{l}1.210^{*} \\
(0.687)\end{array}$ & $\begin{array}{l}1.065 \\
(0.663)\end{array}$ \\
\hline Government Change & & $\begin{array}{l}0.709 \\
(0.556)\end{array}$ & & $\begin{array}{l}0.595 \\
(0.545)\end{array}$ & $\begin{array}{l}0.742 \\
(0.552)\end{array}$ & $\begin{array}{l}0.654 \\
(0.546)\end{array}$ \\
\hline Governance & & $\begin{array}{l}-0.333 \\
(0.403)\end{array}$ & & $\begin{array}{l}-0.126 \\
(0.509)\end{array}$ & $\begin{array}{l}-0.431 \\
(0.546)\end{array}$ & $\begin{array}{l}-0.144 \\
(0.543)\end{array}$ \\
\hline OECD Dummy & & $\begin{array}{l}1.786^{* *} \\
(0.711)\end{array}$ & & $\begin{array}{l}1.610^{* * *} \\
(0.685)\end{array}$ & $\begin{array}{l}2.108^{* * *} \\
(0.958)\end{array}$ & $\begin{array}{l}1.834^{* *} \\
(0.935)\end{array}$ \\
\hline Polity & & $\begin{array}{l}-0.074 \\
(0.048)\end{array}$ & & $\begin{array}{c}-0.071 \\
(0.045)\end{array}$ & $\begin{array}{l}-0.068 \\
(0.064)\end{array}$ & $\begin{array}{l}-0.066 \\
(0.061)\end{array}$ \\
\hline Civil Law Dummy & & $-1.043^{* *}$ & & $-1.185^{* *}$ & $-1.269^{*}$ & $-1.453^{* *}$ \\
\hline
\end{tabular}


Table A5 (continued)

\begin{tabular}{|c|c|c|c|c|c|c|}
\hline & (1) & (2) & (3) & (4) & (5) & (6) \\
\hline & & $(0.496)$ & & $(0.563)$ & $(0.666)$ & $(0.732)$ \\
\hline Observations & 1839 & 1303 & 1839 & 1303 & 967 & 967 \\
\hline Number of Countries & 105 & 94 & 105 & 94 & 94 & 94 \\
\hline Year FE & & & & & YES & YES \\
\hline
\end{tabular}

The dependent variable is a reform dummy that takes the value one in the year when the CBIS index changes. Financial Crisis is a dummy variable that takes the value one if any of the two years prior to a reform year are classified as a systemic banking crisis year in Laeven and Valencia (2013). Same CBIS (World/Continent) represent the share of countries characterised by the same supervisory architecture of the reference country. CBI Reform (GMT) is a dummy variable for countries that have undertaken reforms that modified the degree of independence of their central banks in the same year. Government change is a dummy variable that indicates whether a change in government took place in the past two years. Governance is a World Bank indicator for the level of governance in a country. Polity is a variable capturing the level of democracy of a country. Constant terms are included, but not reported. See Appendix Table A4 for complete variable definitions. Standard errors in parentheses.

**** denotes significance at a $1 \%$ level.

** denotes significance at a $5 \%$ level.

* denotes significance at a $10 \%$ level.

Table A6

Determinants of positive/negative reforms (Peer effects = Geography and Trade).

\begin{tabular}{|c|c|c|c|c|c|c|c|c|}
\hline & \multicolumn{4}{|c|}{ Reforms that increase CBIS } & \multicolumn{4}{|c|}{ Reforms that decrease CBIS } \\
\hline & (1) & $(2)$ & (3) & (4) & (5) & (6) & (7) & (8) \\
\hline Financial Crisis & $\begin{array}{l}1.117^{* *} \\
(0.464)\end{array}$ & $\begin{array}{l}0.793^{*} \\
(0.453)\end{array}$ & $\begin{array}{l}1.217^{* * *} \\
(0.489)\end{array}$ & $\begin{array}{l}0.794 \\
(0.676)\end{array}$ & $\begin{array}{l}-0.180 \\
(0.787)\end{array}$ & $\begin{array}{l}0.112 \\
(0.763)\end{array}$ & $\begin{array}{l}-0.039 \\
(0.791)\end{array}$ & $\begin{array}{l}0.337 \\
(0.830)\end{array}$ \\
\hline Peers - Geographical & $\begin{array}{l}1.439^{* * * *} \\
(0.243)\end{array}$ & $\begin{array}{l}1.642^{* * * *} \\
(0.227)\end{array}$ & & & $\begin{array}{l}0.440 \\
(0.195)\end{array}$ & $\begin{array}{l}0.281 \\
(0.412)\end{array}$ & & \\
\hline Peers - Trade & & & $\begin{array}{l}1.296^{* * * *} \\
(0.189)\end{array}$ & $\begin{array}{l}1.459 \\
(1.063)\end{array}$ & & & $\begin{array}{l}0.268^{*} \\
(0.150)\end{array}$ & $\begin{array}{l}-0.029 \\
(0.204)\end{array}$ \\
\hline \multicolumn{8}{|l|}{ Controls: } & YES \\
\hline \multicolumn{9}{|c|}{ Institutional, Legal factors } \\
\hline Observations & 1810 & 1289 & 1778 & 1249 & 1810 & 1289 & 1778 & 1249 \\
\hline Number of Countries & 102 & 92 & 100 & 89 & 102 & 92 & 100 & 89 \\
\hline
\end{tabular}

The dependent variable is a reform dummy that takes the value one in years when the CBIS index increases in columns (1)-(4) and decreases in columns (5)-(8). Financial Crisis is a dummy variable that takes the value one if any of the two years prior to a reform year are classified as a systemic banking crisis year in Laeven and Valencia (2013). Peers - Geographical/Trade represents the absolute distance between a country's level of CBIS and that of its peers, where the average value of CBIS of peer countries is computed based on geographical distance and trade partners, respectively. Controls include a CBI reform dummy for countries that have undertaken reforms that modified the degree of independence of their central banks in the same year; a government change dummy variable that indicates whether a change in government took place in the past two years; a variable capturing the level of democracy, as well as a world governance indicator; a OECD dummy and civil law dummy variable. Constant terms are included, but not reported. See Appendix Table A4 for complete variable definitions. Standard errors in parentheses.

**** denotes significance at a $1 \%$ level.

** denotes significance at a 5\% level.

" denotes significance at a $10 \%$ level.

Table A7

Determinants of reforms (Robustness with other crises).

\begin{tabular}{|c|c|c|c|c|c|c|}
\hline & (1) & (2) & (3) & (4) & (5) & (6) \\
\hline Currency Crises & $\begin{array}{l}-0.056 \\
(1.065)\end{array}$ & $\begin{array}{l}-0.117 \\
(1.070)\end{array}$ & & & & \\
\hline Recession & & & $\begin{array}{l}-0.659 \\
(0.556)\end{array}$ & $\begin{array}{l}-0.613 \\
(0.550)\end{array}$ & $\begin{array}{l}0.283 \\
(0.434)\end{array}$ & $\begin{array}{l}0.410 \\
(0.436)\end{array}$ \\
\hline Reforms in CBIS (World) & $\begin{array}{l}0.481^{* * * *} \\
(0.142)\end{array}$ & & $\begin{array}{l}0.525^{\text {**** }} \\
(0.136)\end{array}$ & & $\begin{array}{l}0.515^{* * * *} \\
(0.137)\end{array}$ & \\
\hline
\end{tabular}


Table A7 (continued)

\begin{tabular}{|c|c|c|c|c|c|c|}
\hline & (1) & (2) & (3) & (4) & (5) & (6) \\
\hline Reforms in CBIS (Continent) & & $\begin{array}{l}0.080^{\text {******}} \\
(0.015)\end{array}$ & & $\begin{array}{l}0.084^{\text {***** }} \\
(0.015)\end{array}$ & & $\begin{array}{l}0.085^{\text {**** }} \\
(0.015)\end{array}$ \\
\hline CBI Reform (GMT) & $\begin{array}{l}0.793 \\
(0.592)\end{array}$ & $\begin{array}{l}1.404^{\text {*** }} \\
(0.555)\end{array}$ & $\begin{array}{l}0.775 \\
(0.574)\end{array}$ & $\begin{array}{l}1.334^{\text {*** }} \\
(0.547)\end{array}$ & $\begin{array}{l}0.717 \\
(0.580)\end{array}$ & $\begin{array}{l}1.332^{* *} \\
(0.550)\end{array}$ \\
\hline Government Change & $\begin{array}{l}0.564 \\
(0.457)\end{array}$ & $\begin{array}{l}0.743 \\
(0.474)\end{array}$ & $\begin{array}{l}0.594 \\
(0.458)\end{array}$ & $\begin{array}{l}0.762 \\
(0.475)\end{array}$ & $\begin{array}{l}0.523 \\
(0.454)\end{array}$ & $\begin{array}{l}0.718 \\
(0.471)\end{array}$ \\
\hline Governance & $\begin{array}{l}0.267 \\
(0.378)\end{array}$ & $\begin{array}{l}0.137 \\
(0.397)\end{array}$ & $\begin{array}{l}0.262 \\
(0.352)\end{array}$ & $\begin{array}{l}0.102 \\
(0.362)\end{array}$ & $\begin{array}{l}0.142 \\
(0.347)\end{array}$ & $\begin{array}{l}-0.002 \\
(0.356)\end{array}$ \\
\hline OECD Dummy & $\begin{array}{l}1.303^{*} \\
(0.672)\end{array}$ & $\begin{array}{l}1.242^{*} \\
(0.701)\end{array}$ & $\begin{array}{l}1.383^{* * *} \\
(0.649)\end{array}$ & $\begin{array}{l}1.359^{* *} \\
(0.676)\end{array}$ & $\begin{array}{l}1.480 \\
(0.652)\end{array}$ & $\begin{array}{l}1.435^{* * *} \\
(0.677)\end{array}$ \\
\hline Polity & $\begin{array}{l}-0.115^{* * *} \\
(0.055)\end{array}$ & $\begin{array}{l}-0.116 \\
(0.057)\end{array}$ & $\begin{array}{l}-0.116^{* * * *} \\
(0.042)\end{array}$ & $\begin{array}{l}-0.119^{* * * *} \\
(0.043)\end{array}$ & $\begin{array}{l}-0.109^{* *} \\
(0.043)\end{array}$ & $\begin{array}{l}-0.112^{* * * *} \\
(0.043)\end{array}$ \\
\hline Civil Law Dummy & $\begin{array}{l}-1.081^{* *} \\
(0.437)\end{array}$ & $\begin{array}{l}-0.779 \\
(0.453)\end{array}$ & $\begin{array}{l}-1.103^{* *} \\
(0.428)\end{array}$ & $\begin{array}{l}-0.806^{*} \\
(0.441)\end{array}$ & $\begin{array}{l}-1.100 \\
(0.433)\end{array}$ & $\begin{array}{l}-0.786 \\
(0.447)\end{array}$ \\
\hline Observations & 1235 & 1235 & 1293 & 1293 & 1295 & 1295 \\
\hline Number of Countries & 88 & 88 & 94 & 94 & 94 & 94 \\
\hline
\end{tabular}

The dependent variable is a reform dummy that takes the value one in the year when the CBIS index changes. Currency Crisis is a dummy variable that takes the value one if a country has experienced a currency crisis in the previous two years. Recession is a dummy variable that takes the value one if a country has experienced a recession in the previous two years. In columns (3)-(4), recessions are identifies in every year in which a country experience a negative growth in its per capita GDP, while in columns (5)-(6) these episodes are identified following Braun and Larrain (2005). Reforms in CBIS (World/Continent) represent the share of countries that have reformed their financial supervisory structure in the world/continent in the same year. CBI Reform (GMT) is a dummy variable for countries that have undertaken reforms that modified the degree of independence of their central bank in the same year. Government change is a dummy variable that indicates whether a change in government took place in the past two years. Governance is a World Bank indicator for the level of governance in a country. Polity is a variable capturing the level of democracy of a country. Constant terms are included, but not reported. Standard errors in parentheses.

**** denotes significance at a $1 \%$ level.

** denotes significance at a $5 \%$ level.

* denotes significance at a $10 \%$ level.

\section{References}

Abiad, A., Mody, A., 2005. Financial reform: what shakes it? What shapes it?. Am. Econ. Rev. 95 (1), $66-88$.

Agnello, L., Castro, V., Jalles, J.T., Sousa, R.M., 2015. What determines the likelihood of structural reforms? Eur. J. Political Econ. 37 , $129-145$.

Arnone, M., Gambini, A., 2007. Architecture of supervisory authorities and banking supervision. Designing Financial Supervision Institutions: Independence, Accountability and Governance. Edward Elgar, Cheltenham, pp. 262-308.

Arnone, M., Romelli, D., 2013. Dynamic central bank independence indices and inflation rate: a new empirical exploration. J. Financ. Stab. 9 (3), 385-398. Artha, I.K.D.S., de Haan, J., 2015. Financial crises and the dismissal of central bank governors: new evidence. Int. J. Financ. Econ. 20 (1), 80-95.

Beck, T., Demirguc-Kunt, A., Levine, R., 1999. A new database on financial development and structure. Policy Research Working Paper Series 2146. The World Bank. Berger, W., Kißmer, F., 2013. Central bank independence and financial stability: a tale of perfect harmony? Eur. J. Political Econ. 31, 109-118.

Bernanke, B.S., 2007. Central banking and bank supervision in the united states. Technical Report, remarks made at the Allied Social Science Association Annual Meeting, Chicago, Illinois.

Blanchard, O., 2015. Ten Takeaways from the 'Rethinking Macro Policy. Progress or Confusion?'. VoxEU.org.

Blinder, A.S., Ehrmann, M., de Haan, J., Jansen, D.-J., 2017. Necessity as the mother of invention: Monetary policy after the crisis. Econ. Policy (Forthcom.).

Borio, C., Toniolo, G., Clement, P., 2011. The Past and Future of Central Bank Cooperation. Studies in Macroeconomic History. Cambridge University Press.

Braun, M., Larrain, B., 2005. Finance and the business cycle: international, inter-industry evidence. J. Financ. 60 (3), $1097-1128$.

Cerutti, E., Claessens, S., Laeven, L., 2015. The use and effectiveness of macroprudential policies: new evidence. J. Financ. Stab..

Chortareas, G., Logothetis, V., Magkonis, G., Zekente, K.-M., 2016. The effect of banking supervision on central bank preferences: evidence from panel data. Econ. Lett. 140, 11-13.

Čihák, M., Demirgüč-Kunt, A., Feyen, E., Levine, R., 2013. Financial development in 205 economies, 1960 to 2010. Technical Report. National Bureau of Economic Research.

Claessens, S., Ghosh, S.R., Mihet, R., 2013. Macro-prudential policies to mitigate financial system vulnerabilities. J. Int. Money Financ. 39 , $153-185$.

Courtis, N., 2010. How Countries Supervise Their Banks, Insurers and Securities Markets.... Central Banking Publications.

Cukierman, A., 2008. Central bank independence and monetary policymaking institutions - past, present and future. Eur. J. Political Econ. 24 (4), 722-736.

Cukierman, A., Webb, S.B., Neyapti, B., 1992. Measuring the independence of central banks and its effect on policy outcomes. World Bank Econ. Rev. 6 (3), $353-398$.

Dalla Pellegrina, L., Masciandaro, D., Pansini, R., 2013. The central banker as prudential supervisor: does independence matter? J. Financ. Stab. 9 (3),

415-427, (central banking 2.0: Fitting the mainstream).

De Grauwe, P., 2008. There is more to central banking than inflation targeting. First Glob. Financ. Crisis 21st Century, 159.

Di Noia, C., Di Giorgio, G., 1999. Should banking supervision and monetary policy tasks be given to different agencies? Int. Financ. 2 (3), $361-378$.

Dincer, N.N., Eichengreen, B., 2012. The architecture and governance of financial supervision: sources and implications. Int. Financ. 15 (3), $309-325$. 
Dreher, A., Sturm, J.-E., De Haan, J., 2008. Does high inflation cause central bankers to lose their job? Evidence based on a new data set. Eur. J. Political Econ. 24 (4), 778-787.

Elhorst, P., Zandberg, E., de Haan, J., 2013. The impact of interaction effects among neighbouring countries on financial liberalization and reform: a dynamic spatial panel data approach. Spat. Econ. Anal. 8 (3), 293-313.

Goodhart, C., 2008. The regulatory response to the financial crisis. J. Financ. Stab. 4 (4),

351-358, (regulation and the Financial Crisis of 2007-08: Review and Analysis).

Goodhart, C., Schoenmaker, D., 1995. Should the functions of monetary policy and banking supervision be separated? Oxf. Econ. Pap. 47 (4), $539-560$.

Grilli, V., Masciandaro, D., Tabellini, G., 1991. Political and monetary institutions and public financial policies in the industrial countries. Econ. Policy 6 (13), 342-392.

Ioannidou, V.P., 2005. Does monetary policy affect the central bank's role in bank supervision? J. Financ. Intermed. 14 (1), $58-85$.

Kaufmann, D., Kraay, A., Mastruzzi, M., 2010. The worldwide governance indicators: methodology and analytical issues. Policy Research Working Paper Series 5430, The World Bank.

La Porta, R., Lopez-de Silanes, F., Shleifer, A., Vishny, R., 1999. The quality of government. J. Law, Econ. Organ. 15 (1), $222-279$.

Laeven, L., Valencia, F., 2013. Systemic banking crises database. IMF Econ. Rev. 61 (2), 225-270.

Leavy, M.T., Robert, M.R., 2014. Do peer firms affect corporate financial policy? J. Financ. 69 (1), 139-178.

Masciandaro, D., 2006. E pluribus unum? Authorities' design in financial supervision: trends and determinants. Open Econ. Rev. 17 (1), $73-102$.

Masciandaro, D., 2007. Divide et impera: financial supervision unification and central bank fragmentation effect. Eur. J. Political Econ. 23 (2), $285-315$.

Masciandaro, D., 2009. Politicians and financial supervision unification outside the central bank: Why do they do it? J. Financ. Stab. 5 (2), $124-146$.

Masciandaro, D., Quintyn, M., 2009. Reforming financial supervision and the role of central banks: a review of global trends, causes and effects (1998-2008). CEPR Policy Insight 30, 1-11.

Masciandaro, D., Quintyn, M., 2015. The governance of financial supervision: recent developments. J. Econ. Surv..

Masciandaro, D., Quintyn, M., Taylor, M.W., 2008. Inside and outside the central bank: independence and accountability in financial supervision: trends and determinants. Eur. J. Political Econ. 24 (4), 833-848.

Mayer, T., Zignago, S., 2011. Notes on Cepii’s Distances Measures: the Geodist Database.

Melecky, M., Podpiera, A.M., 2013. Institutional structures of financial sector supervision, their drivers and historical benchmarks. J. Financ. Stab. 9 (3), $428-444$.

Peek, J., Rosengren, E.S., Tootell, G.M.B., 1999. Is bank supervision central to central banking? Q. J. Econ. 114 (2), $629-653$.

Persson, T., Tabellini, G., 2009. Democratic capital: the nexus of political and economic change. Am. Econ. J.: Macroecon. 1 (2), 88-126.

PolityIV, 2014. Polity IV Project: Political Regime Characteristics and Transitions, 1800-2014. On-line 〈http://www.systemicpeace.org/inscrdata.html〉.

Romelli, D., 2016. The political economy of reforms in central bank design: evidence from a new dataset. Mimeo Dep. Econ. Trinity Coll. Dublin.

Toniolo, G., 2011. What is a Useful Central Bank. No. 42 in Norges Bank Occasional Papers. Ch. What is a useful central bank? Lessons from interwar years.

Ugolini, S., 2011. What do we really know about the long-term evolution of central banking? Evidence from the past, insights for the present. Working Paper 2011/15, Norges Bank.

Waelti, S., 2015. Financial crisis begets financial reform? The origin of the crisis matters. Eur. J. Political Econ. $40,1-15$.

World Bank, 2014. World development indicators 2014. Technical Report. World Bank Publications. 